This PDF is a selection from a published volume from the National Bureau of Economic Research

Volume Title: Growth and Productivity in East Asia, NBER-East Asia Seminar on Economics, Volume 13

Volume Author/Editor: Takatoshi Ito and Andrew K. Rose, editors

Volume Publisher: University of Chicago Press

Volume ISBN: 0-226-38680-5

Volume URL: http://www.nber.org/books/ito_04-2

Conference Date: June 20-22, 2002

Publication Date: June 2004

Title: GATT/WTO Accession and Productivity

Author: David D. Li, Changqi Wu

URL: http://www.nber.org/chapters/c10746 


\section{GATT/WTO Accession and Productivity}

David D. Li and Changqi Wu

\subsection{Introduction}

In the era of globalization, the event of an economy's accession to the World Trade Organization (WTO) invariably attracts widespread attention. The recent events of China's successful accession to the WTO and Russia's push to obtain WTO membership are just two such instances. Many developing and emerging-market countries believe that the accession to the WTO would enhance their productivity and economic prosperity. Nevertheless, the real impact of the accession to the WTO on the productivity of a developing or emerging-market economy remains unanswered.

The WTO, whose former incarnation is the General Agreement on Trade and Tariff (GATT), is an international organization with 144 economies as its members in 2002. It has played a significant role in promoting international trade and pushing for greater integration of the world economy. In GATT's forty-eight years of history until 1994, trade barriers among member economies fell significantly. Under the three main principles of "most-favored-nation status," "national treatment," and "consensus," GATT members engaged in seven rounds of negotiations. As a result,

David D. Li is associate professor of economics and associate director of the Center for Economic Development at the Hong Kong University of Science and Technology. Changqi $\mathrm{Wu}$ is adjunct associate professor of economics at the Hong Kong University of Science and Technology.

We would like to thank two discussants, Simon Johnson and Epictetus Patalinghug; the seminar chairs, Takatoshi Ito and Andrew Rose; and participants at the Thirteenth NBEREast Asian Seminar on Economics for their comments and suggestions. We would also like to thank David W. Fan for his excellent research assistance. The financial support of Hong Kong Research Grant Council (RGC HKUST6072/01HHKUST6227/03H) is gratefully acknowledged. 
tariffs on traded manufactured goods fell from an average of 40 percent before the organization was established to less than 5 percent in the 1990s. Meanwhile, the volume of international trade has been increasing twice as fast as the output of the world since the 1950s.

The event of accession to GATT/WTO is actually an important testing case of the much more general and bigger issue of globalization, which has been controversial. We summarize that there are two broad groups of controversies about globalization. The first group of controversies is general. They are about who, if anyone, benefits from globalization. There have been econometric studies of the positive impact of trade liberalization on economic growth and development (e.g., Harrison 1996). More generally, the view of the advantage of backwardness that low-income economies ought to benefit from opening up to the world economy, as popularized by Alexander Gerschenkron's theory of the advantage of backwardness (Gerschenkron 1962), seems to be widely accepted. However, some have challenged whether openness is a by-product or measure of other more fundamental changes in the domestic economy (e.g., Rodriguez and Rodrik 2000; Kenny and Williams 2001). According to this view, "integration into the world economy" cannot "substitute for a development strategy." Furthermore, after the recent Asian financial crises, some argue that the globalization, especially hastened by improper order of sequencing, can produce a detrimental effect on developing countries (Rodrik 1997; Stiglitz 2002).

The second cluster of controversies is about particular consequences of opening up. For example, what will happen to inward foreign direct investment (FDI) once a country opens up? One often-made argument is that inward FDI will fall based on the tariff-jumping theory (Brecher and Diaz-Alejandro, 1977). That is to say, FDI is an alternative way to enter a market when export is not a feasible option under high import tariffs before a country joins GATT/WTO. Import and FDI are substitutes. The drastic reduction in import tariffs makes direct export to the target market a feasible option. After a country joins the GATT/WTO, therefore, the FDI will fall. A competing hypothesis is that FDI will increase after a country opens up. This happens because a reduction of trade barriers makes the economy more likely to become a production base to serve the world market. In turn, more FDI results in increases in intrafirm trade in intermediate goods so that the volume of international trade will also increase. Hence, FDI and exports are complements.

Accession to GATT/WTO provides a useful event study to facilitate the debates on these two sets of issues. The accession cases happen relatively quickly so that simultaneous changes in other factors are easy to control for. Also, by comparing what happened before and after the accession in an accession economy, one can control for heterogeneity across different economies. Both factors are advantages over cross-sectional studies covering many years. 
We are not aware of any systematical study assessing the impact of the GATT/WTO accession across countries, although there are many countryspecific studies of GATT/WTO accessions, such as Milthorp (1997); Mutti, Sampson, and Yeung (2000); and Fernandez de Cordoba and Kehoe (2000). A recent exception is Rose (2002), who finds that WTO accession did not visibly increase an economy's trade. This is surprising, given the existence of widely different theories and opinions on these issues and extensive observations of the event of GATT/WTO accession.

Apparently, the impact of the GATT/WTO accession is likely to be different on different types of economies. We therefore classify the economies in two alternative ways. The first approach is to divide the sample economy into two groups by the level of per capita GDP of 1987, the median year of our sample. We call the economies with per capita GDP over US $\$ 3,000$ high-income economies and others low-income ones. This classification is motivated by Gerschenkron's theory of the advantage of backwardness. Another classification is by the institutional configuration of an economy. We are inspired by the work of La Porta et al. (1999), who argue that the origin of the economy's legal institutions is a key factor affecting economic performance. We thus divide the economies into common-law economies, continental European law economies, and formerly socialist systems. Our classification of the economies in this fashion comes from La Porta et al. (1999).

\subsection{The Data Set and Methodology}

In spirit, we are following the method of "event study."1 That is, we collect data on those economies before and after they became members of GATT/WTO and study whether there are significant changes in those economies. In doing so, we also need to include in our sample countries that did not join GATT/WTO in the same period, including countries that had already been members of the GATT/WTO by the beginning of the sample year. The method of event study has been widely used in economics and finance literature. An advantage of event study over standard crosssection or time series analysis is that it enables us to concentrate on the event itself, which usually happens in a short time window with few other changes at the same time.

\subsubsection{The Data Set}

Our sample covers 112 economies from 1960 to 1998. The sample consists of almost all economies in the world, except those that underwent prolonged wars during the covered years, such as the Congo, Iran, Iraq, and

1. See MacKinlay (1997) for a detailed survey of event study methods applied in economics and finance. 
so on, and economies that have had major boundary changes during the sample years, since we cannot find consistent economic statistics on those boundary-changing economies over time. Examples in the latter group include most of the former Soviet republics. Table 4.1 lists the names of all economies in the sample with their descriptive statistics.

The sample consists of seventy-four economies that joined GATT/WTO during the sample years and eighteen economies that had already joined GATT/WTO by 1960 and twenty that had not become members of GATT/ WTO by 1998. The latter group forms a reference for us to examine the impact of GATT/WTO accessions. Also, we classify the sample economies by the level of per capita GDP in 1987. This way, we divide the sample into high-income and low-income economies. We also classify the sample economies by their legal economic systems: common law, continental European law, and socialist economic system. Table 4.2 provides summary statistics of the different types of the sample economies.

Data sources include the World Investment Report of the United Nations Conference on Trade and Development (UNCTAD), the International Financial Statistics (IFS) of the International Monetary Fund (IMF), World Development Indices (WDI) of the World Bank, and publications by GATT/WTO.

\subsubsection{Economic Variables Examined}

We are interested in two sets of economic indices of the accession economies. The first set of economic variables is GDP, export in constant U.S. dollars and constant local currency, the ratio of import and export to GDP, logarithm of FDI, and the ratio of FDI to GDP, respectively. These variables measure the openness of the economy. The second economic index of our concern is the growth rate of total factor productivity (TFP), which is the term in the aggregate production function besides those of capital and labor. The TFP is a measure of the overall efficiency of the economy.

\subsubsection{The Duration of the Impact of the Accession}

In modeling the impact of the GATT/WTO accession, we need to specify the duration of the impact. One cannot expect the accession to have a permanent impact on the growth rate of the economic variables of the economy while a permanent shift in the level of the economic variable is likely. Ideally, with a long enough time horizon in panel data, one can endogenously specify the time pattern of the impact. Unfortunately, this is not the case in the study, since we only have thirty-nine years of observation in total for a typical country, and for a typical accession economy we only have fifteen years of observation after accession.

Facing this limit, we constrain our model to the specification that the impact of the accession is within ten years. That is, starting from the 


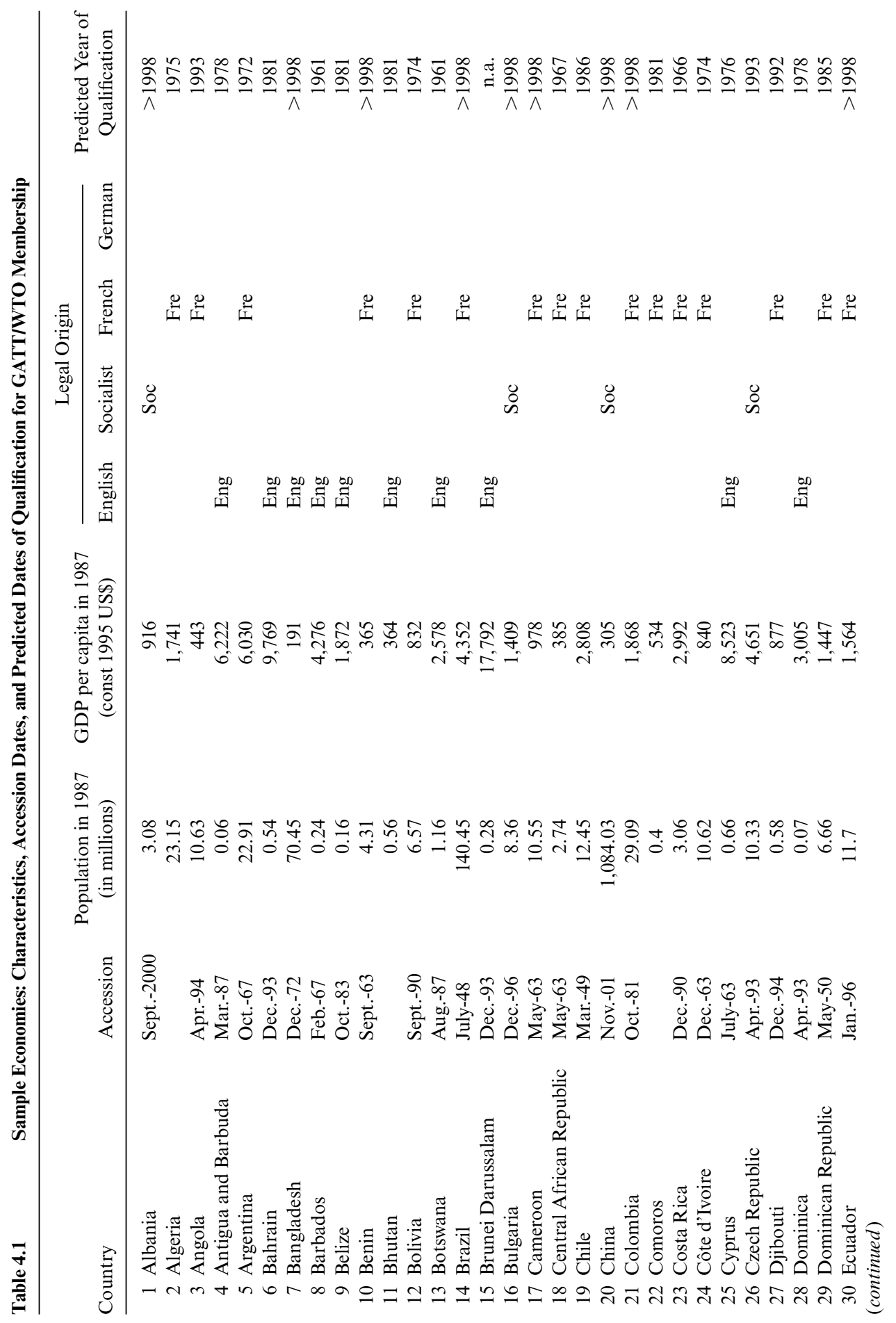




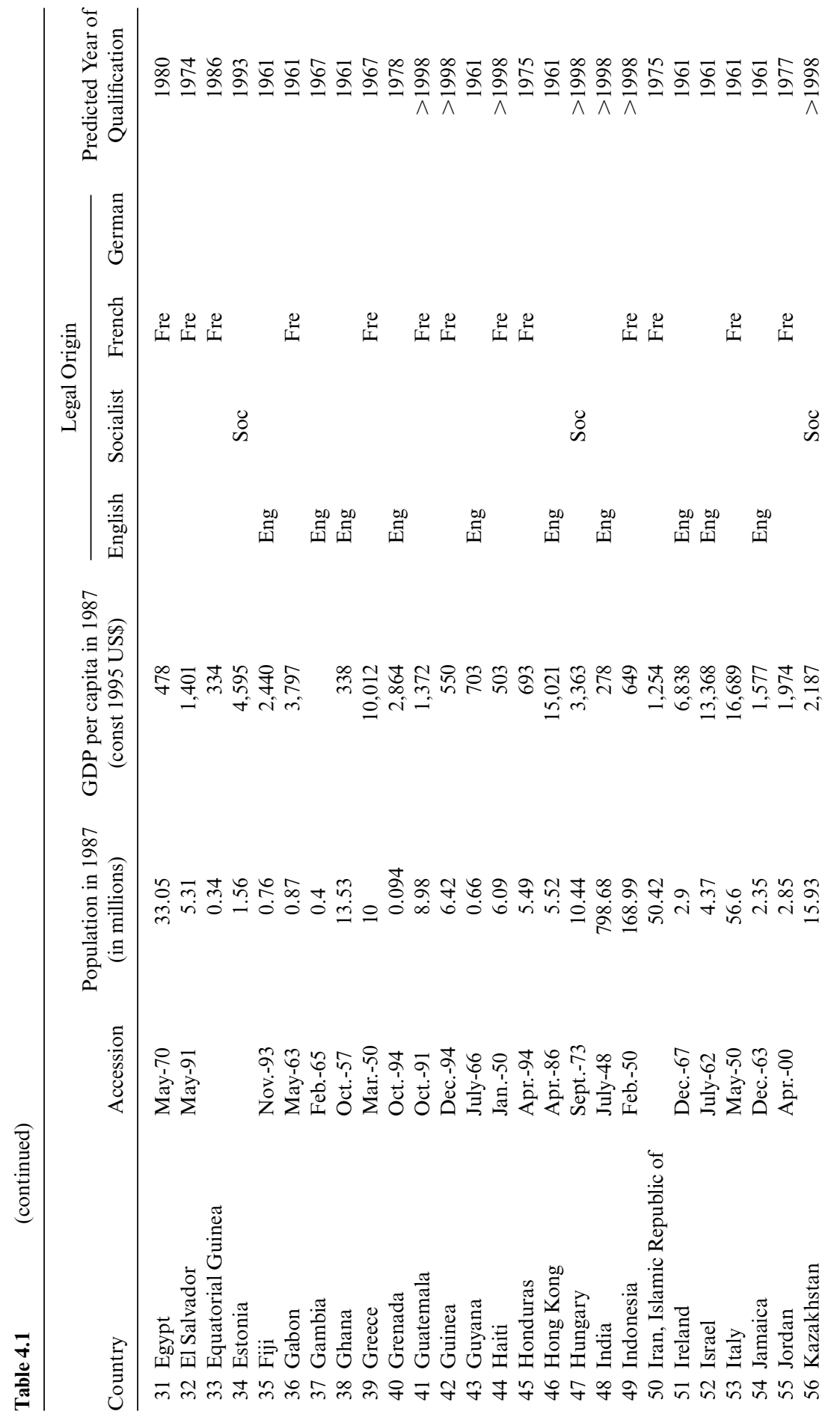




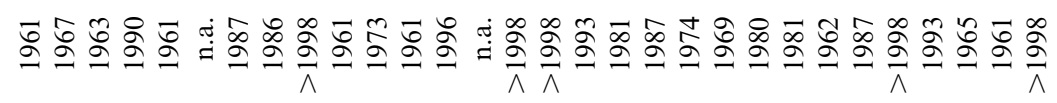

这

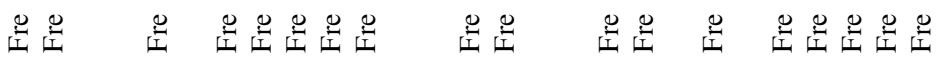<smiles>CC1([V])CCCCC1</smiles>

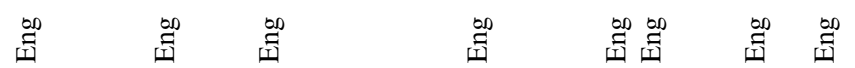

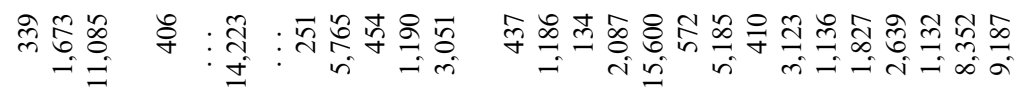

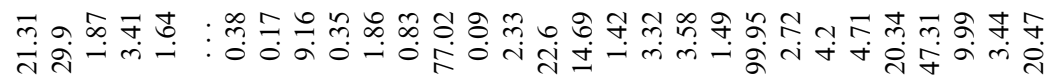

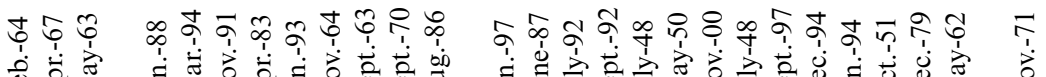

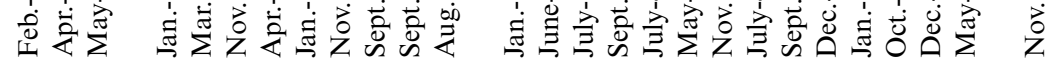

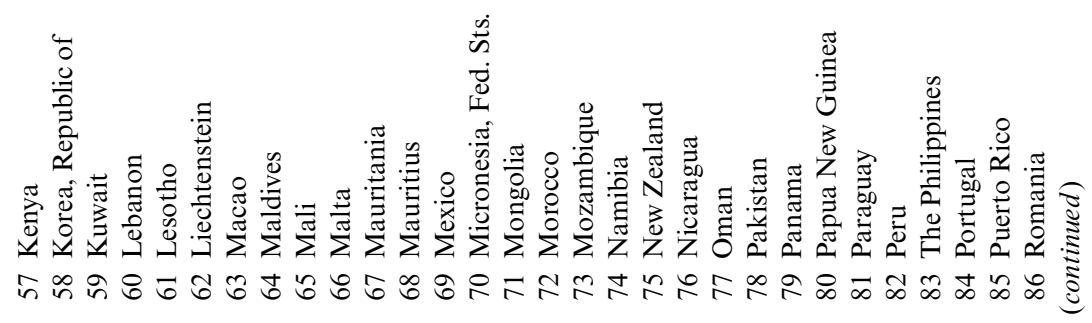




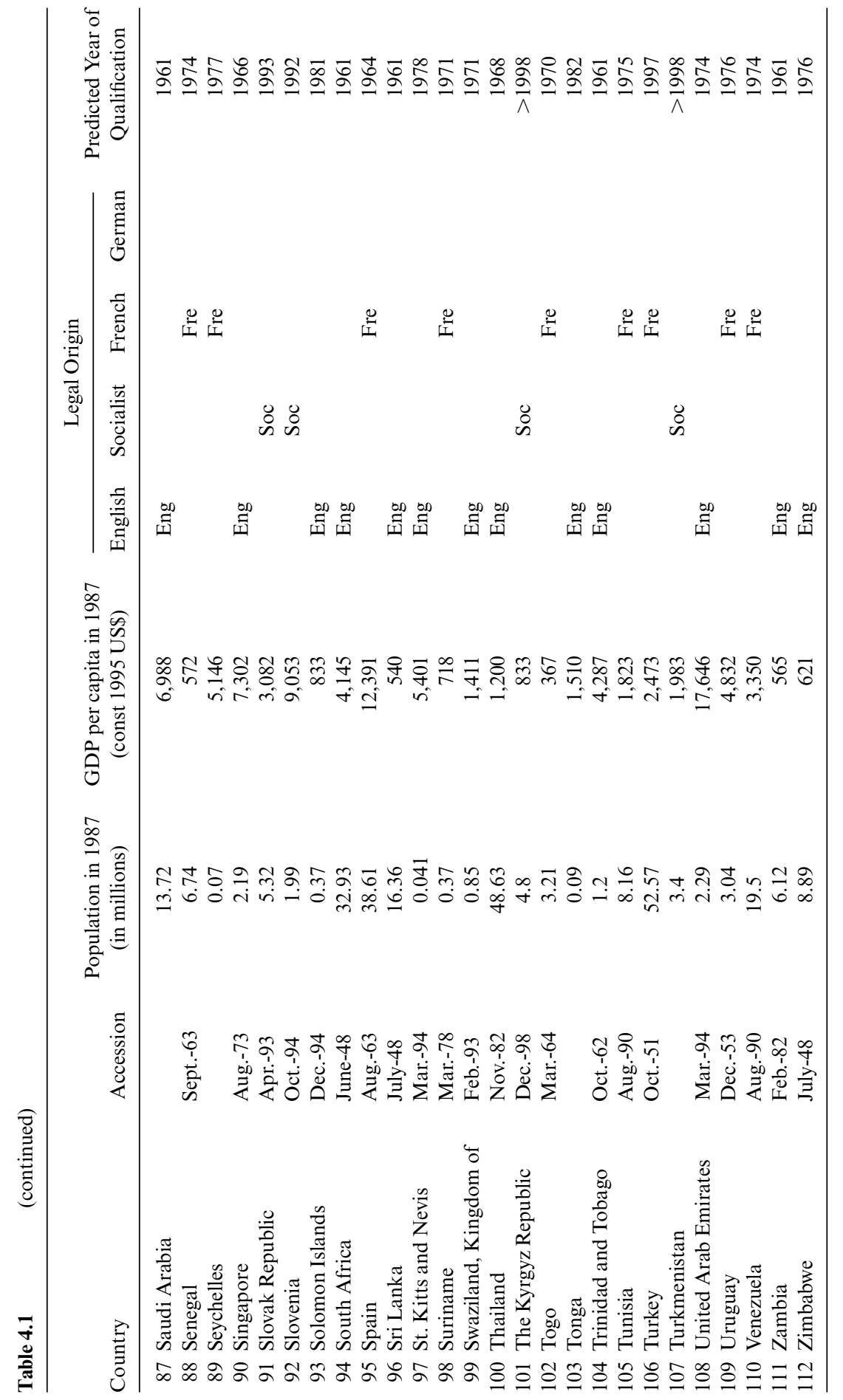




\begin{tabular}{lcccc}
\hline & $\begin{array}{c}\text { Accession } \\
\text { Economies } \\
\text { before } \\
1951\end{array}$ & $\begin{array}{c}\text { Accession } \\
\text { Economies } \\
\text { within } \\
1951-1998\end{array}$ & $\begin{array}{c}\text { Accession } \\
\text { Economies } \\
\text { after } \\
1998\end{array}$ & Nonmembers \\
\hline $\begin{array}{l}\text { Average population in 1987 } \\
\quad \text { (in millions) }\end{array}$ & 97.5 & 11.2 & 273 & 8.3 \\
$\begin{array}{l}\text { Average per capita GDP in 1987 } \\
\quad \text { in 1995 US\$) }\end{array}$ & $4,187.6$ & $3,734.6$ & $2,095.0$ & $2,985.3$ \\
$\begin{array}{l}\text { Average import/GDP ratio in } \\
\quad \text { 1987 (\%) }\end{array}$ & 22.1 & 45.2 & 29.5 & 43.58 \\
$\begin{array}{l}\text { Average export/GDP ratio in } \\
\quad \text { 1987 (\%) }\end{array}$ & 20 & 40.5 & 28.1 & 31.9 \\
$\begin{array}{l}\text { No. of economies of common } \\
\text { law origin }\end{array}$ & 6 & 31 & 0 & 4 \\
$\begin{array}{l}\text { No. of former Socialist systems } \\
\text { No. of economies of continental } \\
\text { European legal origin }\end{array}$ & 8 & 39 & 2 & 7 \\
\hline
\end{tabular}

Note: There are two countries (Korea and Liechtenstein) that belong to the German legal system. Therefore, the total number of countries in this table is 110 .

accession year, the growth rate of the economic variables of our concern may have a constant upward shift in each year. After the tenth year, there is no change in the growth rate. We also repeated all the estimation procedures by using eight and twelve years as the alternative time span of impact, and the results are very similar. This gives us confidence that ten years is a good approximation of the duration of the accession effect on an economy.

\subsubsection{The Classification of Economies}

We classify the economies in two alternative ways in order to examine potentially different effects of the GATT/WTO accessions. The two classifications are most likely to be relevant to explaining an economy's response to its GATT/WTO accession. The first classification is by per capita GDP. We follow the World Bank classification and use the economies' per capita GDP in 1987 to divide all the sample economies into high-income and medium- or low-income economies. The dividing per capita GDP level is 3,000 constant U.S. dollars in 1987. In principle, we can also have more refined classification by further dividing the economies with per capita income below US $\$ 3,000$ into medium- and low-income groups. However, there is a data constraint that prevents us from estimating models with such refined classifications: We do not have many low-income economies that joined GATT/WTO during the sample years.

The second classification is by initial social economic institutions. We have three categories: economies that originated from common-law legal institutions, from continental European legal institutions, and from so- 
cialist systems, respectively. The classification is borrowed from La Porta et al. (1999). In theory, one can further divide the continental European law countries into the French type, the German type, and the Scandinavian type. Again, the data set does not contain enough economies to allow us to go into such detailed classification. In the study, we group French, German, and Scandinavian economies into the category of continental European legal origin.

\subsubsection{Dealing with the Endogeneity Issue of GATT/WTO Accessions}

Our objective is to study the impact of the event of the accession to GATT/WTO on the accession economy. To achieve that goal, we must deal with the question of endogeneity. That is, it is likely that economies did not or were not selected randomly to join GATT/WTO, and by the time an economy was able to access to GATT/WTO, its economic performance already began to be different from its past and from those non-GATT/WTO members. This is a classical sample selection problem. In other words, when we see an economy's performance improved after its GATT/WTO accession, was the improvement due to the action of the accession and subsequent policy and institutional changes? Or was it due to the fact that the economy in question had reached a new plateau of economic development and openness, enabling it to have better economic performance than before, which was certified by existing members of GATT/WTO in approving it to be a new member?

This is a critical and often pesky issue in similar empirical studies. We take two alternative methods to deal with the sample selection problem. The first method is due to Heckman and Hotz (1989). The idea is that if an economy, indexed by $i$, is chosen in year $t$ to be a member of GATT/WTO, $i$ must already have been intrinsically different by year $t$, which enables existing members of GATT/WTO to award membership to country $i$ in year $t$. Although we obviously cannot measure how intrinsically different $i$ had become by year $t$, we can generate a variable called the selection variable as a regressor in the regressions to capture this effect. The selection variable takes on the value 0 before year $t-2$ and then the values of $1,2,3,4, \ldots$ for the subsequent years of $t-2, t-1, t+1, \ldots$, respectively. The estimated coefficients of the selection variable tell us how intrinsically different an accession economy is starting from two years before the accession. For instance, in a regression of $\log (\mathrm{GDP})$, if the coefficient of the selection variable is 0.02 and statistically significant, then this tells us that, on average, those economies that joined GATT/WTO began to perform differently two years before the accession. Their GDP level was 2 percent higher each year two years before the actual accession year until one year after the accession year. This hypothetical finding would imply that the GATT/WTO accession mechanism selected those economies that had an initial jump in GDP 
to be new members. In the same regression, the WTO dummy that takes on nonzero values after the year of accession is left to capture the actual accession effect that we are interested in.

Why did we choose the $t-2$ to $t$ time window for the selection variable? The answer is that we also experimented with alternative configurations, including $t-5$, or $t-4$, or $t-3$ to $t+1$, or $t+2$. The findings are qualitatively similar, so we only report the $t-2$ to $t$ results.

The other approach that we adopted to deal with the endogeneity issue of GATT/WTO accessions is to explicitly model the endogenous selection effect. We model the endogenous selection effect as one that starts to exist when an economy is perceived to be qualified and acceptable to be a member of GATT/WTO. Let us call this the qualification date. Note that the qualification date and the actual accession date, in principle, are different and separated by noneconomic and random factors, such as political and diplomatic disputes. The qualification date may be earlier than the actual accession date, since political issues may delay accession negotiations; for example, the midair collision of military aircraft in the South China Sea in 2001 significantly slowed down China's scheduled accession negotiations with the United States. Similarly, the qualification date may be later than the accession date in cases of premature accessions, when some existing members of GATT desired earlier acceptance of a nonmember economy for political considerations. Examples include Hungary in the 1970s, when it was still a socialist economy but was relatively politically friendly to the West and therefore was eagerly accepted by Western members of the GATT.

The strategy for us to implement the foregoing idea consists of two steps. First, we try to explain econometrically when an economy is qualified to be a member of WTO. To do this, we run a probit regression explaining the event of GATT/WTO accession. The implicit assumption is that the actual date of accession and the qualification date are separated by random noise. The independent variables are lagged per capita income, import-GDP, export-GDP, and legal origin. Second, we use the fitted probit regression to predict when an economy is qualified to be a member of the WTO. We then use this estimated qualification date to generate a selection dummy variable for use in our main regressions in order to isolate and capture the selection effect. The selection dummy is 0 before the qualification date and is $1,2,3, \ldots$, afterward. That is, we model that after an economy is qualified to be a member of GATT/WTO, it might be on a growth path different from the variable of our concern.

Note that the actual accession effect, which is our main concern, rather than the selection effect, by definition only starts to take place upon the actual accession of an economy to GATT/WTO. Thus, in regression, we can use the accession dummy as an independent variable to capture this effect. 


\subsubsection{The Econometric Models}

We estimate two sets of econometric models. The first one is to examine the impact of accession on individual economic variables of the economy such as GDP, capital stock, import and export, and FDI. Let $x_{i t}$ be the one of the variables previously mentioned, and the first set of regressions are as follows:

(1) $\log \left(x_{i t}\right)=\alpha_{i}+\sum_{j=1}^{J}\left(\beta_{j} T_{t}+\gamma_{j}\right.$ Selection $\left._{i t}+\delta_{j} \mathrm{WTO}_{i t}\right) j \mathrm{Dummy}_{i t}+\varepsilon_{i t}$,

where $\alpha_{i}$ is a country-specific scale factor, which allows different countries to have different initial levels of economic variable $x$; that is, it is the fixed effects coefficient. $j$ is an index of the type of the economy (e.g., high income or low income; common law, continental law, or formerly socialist economy). $\beta_{j}$ is type J economy's normal growth rate of variable $x . T_{t}$ is time trend, equaling to $1,2, \ldots$, for the years of 1960,1961 , respectively. $\gamma_{j}$ is the coefficient capturing the endogenous selection effect of GATT/WTO accessions. Selection ${ }_{i t}$ is a variable to index the selection effect. There are two alternative methods to valuate Selection ${ }_{i t}$, corresponding to the two alternative methods explained above. $\mathrm{WTO}_{i t}$ is the timer of the actual accession: It equals to $1,2, \ldots, 10$, for the first, second, . , tenth year of accession, and it remains at the level of 10 after the tenth year of accession. Finally, we assume that the error term $\varepsilon_{i t}$ is independent across country (indexed by $i$ ) but might be correlated across time (indexed by $t$ ).

As explained, we use two alternative measures of the variable Selection ${ }_{i t}$. The first method comes from Heckman and Hotz (1989) and lets Selection be equal to 0 until three years before the accession, when it becomes 1, 2, 3 for the three years right before the accession. After the accession, Selec$\operatorname{tion}_{i t}$ stays at 3 . $\delta_{j}$ is the coefficient of the actual accession impact, which is our main concern. Figure 4.1 illustrates the valuation of Selection ${ }_{i t}$ in this method together with the $\mathrm{WTO}_{i t}$ variable.

The alternative valuation of Selection ${ }_{i t}$ is the following. Let $\mathrm{ACC}_{i t}=0$ or $\mathrm{ACC}_{i t}=1$ depending on our prediction of whether country $i$ is already a member of GATT/WTO by year $t$. The prediction is based on a fitted probit regression of GATT/WTO membership on one-year lagged per capita income, import-GDP, export-GDP, and legal origin. As for Selection ${ }_{i t}$, it is 0 if $\mathrm{ACC}_{i t}=0$ and it is $1,2,3, \ldots$, respectively, after the first year in which $\mathrm{ACC}_{i t}=1$.

The economic interpretation of model (1) is that for a type $J$ economy, the economic variable $x$ has a steady-state growth rate of $\beta_{i}$, and after the accession, within ten years, the growth rate further changes by $\delta_{j} . \gamma_{j}$ captures the effect on the economy when the economy is selected or qualified to be a member of GATT/WTO.

The second set of regressions that we estimate are for discovering the im- 


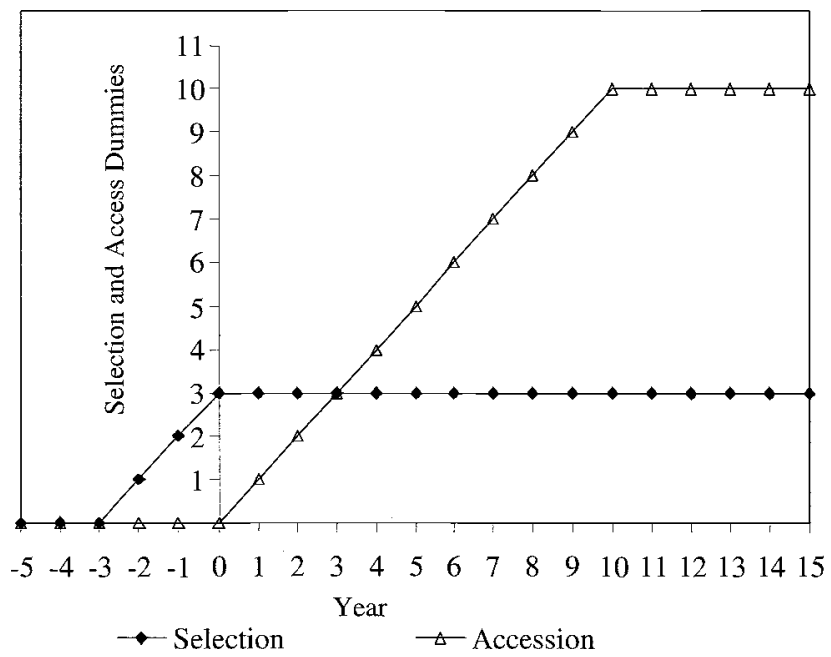

Fig. 4.1 The selection effect and the accession effect

Note: Year 0 stands for the accession year.

pact of the GATT/WTO on productivity changes in the economy. The model is as follows:

(2) $\log \left(\mathrm{GDP}_{i t}\right)=\alpha_{i}+\sum_{j=1}^{J}\left(\beta_{j} T_{t}+\gamma_{j}\right.$ Selection $\left._{i t}+\delta_{j} \mathrm{WTO}_{i t}\right) j$ Dummy $_{i t}$

$$
\begin{aligned}
& +\beta_{\text {Import }}\left(\frac{\text { Import }}{\mathrm{GDP}}\right)_{i t}+\beta_{\text {Export }}\left(\frac{\text { Export }}{\mathrm{GDP}}\right)_{i t} \\
& +\beta_{\mathrm{FDI}}\left(\frac{\mathrm{FDI}}{\mathrm{GDP}}\right)_{i t}+\sum_{q=\text { LowIncome }_{q K}^{\text {HighIncome }}}\left[\beta_{i t} \log \left(\text { Capital }_{i t}\right)\right. \\
& \left.+\beta_{q L} \log \left(\text { Labor }_{i t}\right)\right] q \text { Dummy }_{i t}+\varepsilon_{i t},
\end{aligned}
$$

where $\alpha_{i}$ is a country-specific coefficient capturing initial productivity differences among countries (i.e., the fixed effects coefficient). $\beta_{\text {Import }}$, $\beta_{\text {Export }}$, and $\beta_{\mathrm{FDI}}$ are the coefficients measuring the potential influence of openness on the economy's productivity. $\gamma_{j}$ and $\delta_{j}$ are parameters to capture the selection and the accession impact, respectively, similar to model (1). $\beta_{q K}$ and $\beta_{q L}$ are the elasticity coefficients of capital and labor, respectively, for income group $q . q$ indexes either high-income or low-income countries, since high-income and low-income economies may adopt different production technology. That is, we allow the possibility that the capital and labor elasticities vary across different types of economies. All other variables and parameters are the same as or similar to those in equation (1). 
Table 4.3

A Probit Regression of GATT/WTO Membership

\begin{tabular}{lc}
\hline Independent Variable & $\begin{array}{c}\text { WTO/GATT Membership (Yes }=1) \\
\text { (panel data probit with random effect) }\end{array}$ \\
\hline One Year Lagged Per Capita GDP & $0.00014^{* * *}$ \\
One Year Lagged Import/GDP & $(12.79)$ \\
& $0.023^{* * *}$ \\
One Year Lagged Export/GDP & $(8.87)$ \\
& $0.0080^{* * *}$ \\
Continental Law Origin Dummy & $(2.89)$ \\
& $-0.50^{* * *}$ \\
Socialist Origin Dummy & $(-5.03)$ \\
& $-1.48^{* * *}$ \\
Intercept & $(-5.08)$ \\
& $-0.64^{* * *}$ \\
Wald Chi-Square(5) & $(-5.39)$ \\
No. of observations & 419.83 \\
\hline
\end{tabular}

Note: $T$-statistics are in parentheses.

***Significant at the 1 percent level.

**Significant at the 5 percent level.

*Significant at the 10 percent level.

\subsection{The Findings}

\subsubsection{Predictions of the Qualification for GATT/WTO Membership}

Table 4.3 reports the estimation results of the probit regression of the GATT/WTO membership. The dependent variable is whether country $i$ had already become a member of GATT/WTO by year $t$ with 1 corresponding to yes and 0 to no, respectively. This is to be used to predict which economies would be qualified to be members of GATT/WTO at various years, which, in turn, is used to capture the selection effect of the GATT/ WTO accessions. As expected, it shows that an economy's GDP per capita is a significant predictor of its GATT/WTO membership. So is the extent of the economy's openness as measured by import-GDP, export-GDP, and FDI-GDP. Meanwhile, other things being equal, economies with common-law origins are more likely to be members of GATT/WTO than those with continental-law origins and socialist economies. This is perhaps because economies with common-law origins are more credibly adaptable to externally imposed regulations of GATT/WTO.

Based on the estimation results, we predict which economies would begin to be qualified as members of GATT/WTO, and by which year. Tables 4.4 to 4.6 give the predictions. Among the 18 economies that were already GATT members before 1960, we predicted that 13 of them would have 
The Actual and Predicted Accession Years for Economies that Had Been Members of GATT by 1960

\begin{tabular}{llc}
\hline Country & Accession Year & $\begin{array}{c}\text { Predicted } \\
\text { Accession Year }\end{array}$ \\
\hline \multicolumn{1}{c}{ Predicted to be Members of GATT/GATT } & (13 economies) \\
South Africa & June 1948 & $<1960$ \\
New Zealand & July 1948 & 1987 \\
Pakistan & July 1948 & 1980 \\
Sri Lanka & July 1948 & $<1960$ \\
Zimbabwe & July 1948 & 1976 \\
Chile & March 1949 & 1986 \\
Greece & March 1950 & 1967 \\
Dominican Republic & May 1950 & 1985 \\
Italy & May 1950 & $<1960$ \\
Nicaragua & May 1950 & 1974 \\
Turkey & October 1951 & 1997 \\
Uruguay & December 1953 & 1976 \\
Ghana & October 1957 & $<1960$ \\
Predicted Not to be Members of GATT/WTO before 1998 (5 economies) & n.a. \\
Brazil & July 1948 & n.a. \\
India & July 1948 & n.a. \\
Haiti & January 1950 & n.a. \\
Indonesia & February 1950 & n.a. \\
Peru & October 1951 & \\
& &
\end{tabular}

joined GATT either before 1960 or during 1960-98. Out of the 18 economies, 5 were predicted not to have joined GATT/WTO by 1998. For the 74 economies that joined GATT/WTO between 1960 and 1998, 45 economies were predicted to have joined before the actual accession year; 15 were predicted to have joined after the actual date; and 14 were predicted to have never accessed in the 1960-98 window. Finally, for the 20 economies that had not joined GATT/WTO by 1998, we predicted that 11 of them would have joined by 1998 and 5 otherwise (for 4 other economies, we do not have available data to make the predictions).

\subsubsection{Impact on Import, Export, and Foreign Direct Investment}

Tables 4.7 to 4.10 report results of regressions of various measures of import. As dependent variable, the regressions use three alternative measures of imports: import in constant U.S. dollars, import in constant local currency, and the ratio of import to GDP (both are in constant local currency and the ratio is in percentage). Note that the ratio of import to GDP is often regarded as a measure of openness of the economy.

Looking at the regressions with income dummies as reported in tables 4.7 and 4.8 , one can easily find a consistent pattern. That is, after accession, 


\begin{tabular}{|c|c|c|}
\hline Country & Accession Year & $\begin{array}{c}\text { Predicted } \\
\text { Accession Year }\end{array}$ \\
\hline \multicolumn{3}{|c|}{ Economies Whose Predicted Accession was Earlier than Actual Accession (45 economies) } \\
\hline Angola & April 1994 & 1993 \\
\hline Antigua and Barbuda & March 1987 & 1978 \\
\hline Bahrain & December 1993 & 1981 \\
\hline Barbados & February 1967 & $<1960$ \\
\hline Belize & October 1983 & 1981 \\
\hline Bolivia & September 1990 & 1974 \\
\hline Botswana & August 1987 & $<1960$ \\
\hline Costa Rica & December 1990 & 1966 \\
\hline Czech Republic & April 1993 & 1993 \\
\hline Djibouti & December 1994 & 1992 \\
\hline Dominica & April 1993 & 1978 \\
\hline El Salvador & May 1991 & 1974 \\
\hline Fiji & November 1993 & $<1960$ \\
\hline Gabon & May 1963 & $<1960$ \\
\hline Grenada & October 1994 & 1978 \\
\hline Guyana & July 1966 & $<1960$ \\
\hline Honduras & April 1994 & 1975 \\
\hline Hong Kong & April 1986 & 1961 \\
\hline Ireland & December 1967 & $<1960$ \\
\hline Israel & July 1962 & $<1960$ \\
\hline Jamaica & December 1963 & $<1960$ \\
\hline Kenya & February 1964 & $<1960$ \\
\hline Korea, Republic of & April 1967 & 1967 \\
\hline Kuwait & May 1963 & 1963 \\
\hline Lesotho & January 1988 & $<1960$ \\
\hline Macao & November 1991 & 1987 \\
\hline Malta & November 1964 & $<1960$ \\
\hline Mauritius & September 1970 & $<1960$ \\
\hline Namibia & September 1992 & 1981 \\
\hline Panama & September 1997 & 1981 \\
\hline Papua New Guinea & December 1994 & 1962 \\
\hline Paraguay & January 1994 & 1987 \\
\hline St. Kitts and Nevis & March 1994 & 1978 \\
\hline Singapore & August 1973 & 1966 \\
\hline Slovak Republic & April 1993 & 1993 \\
\hline Slovenia & October 1994 & 1992 \\
\hline Solomon Islands & December 1994 & 1981 \\
\hline Suriname & March 1978 & 1971 \\
\hline Swaziland, Kingdom of & February 1993 & 1971 \\
\hline Thailand & November 1982 & 1968 \\
\hline Trinidad and Tobago & October 1962 & $<1960$ \\
\hline Tunisia & August 1990 & 1975 \\
\hline United Arab Emirates & March 1994 & 1974 \\
\hline Venezuela & August 1990 & 1974 \\
\hline Zambia & February 1982 & $<1960$ \\
\hline
\end{tabular}


(continued)

\begin{tabular}{|c|c|c|}
\hline Country & Accession Year & $\begin{array}{c}\text { Predicted } \\
\text { Accession Year }\end{array}$ \\
\hline \multicolumn{3}{|c|}{ Economies Whose Predicted Accession was Later than Actual Accession (15 economies) } \\
\hline Argentina & October 1967 & 1972 \\
\hline Central African Republic & May 1963 & 1967 \\
\hline Côte d'Ivoire & December 1963 & 1974 \\
\hline Cyprus & July 1963 & 1976 \\
\hline Egypt & May 1970 & 1980 \\
\hline Gambia & February 1965 & 1967 \\
\hline Maldives & April 1983 & 1986 \\
\hline Mauritania & September 1963 & 1973 \\
\hline Mexico & August 1986 & 1996 \\
\hline Mozambique & July 1992 & 1993 \\
\hline The Philippines & December 1979 & 1993 \\
\hline Portugal & May 1962 & 1965 \\
\hline Senegal & September 1963 & 1974 \\
\hline Spain & August 1963 & 1964 \\
\hline Togo & March 1964 & 1970 \\
\hline \multicolumn{3}{|c|}{ Economies that Are Predicted Not to Join GATT/WTO by 1998 (14 economies) } \\
\hline Bangladesh & December 1972 & n.a. \\
\hline Benin & September 1963 & n.a. \\
\hline Bulgaria & December 1996 & n.a. \\
\hline Cameroon & May 1963 & n.a. \\
\hline Colombia & October 1981 & n.a. \\
\hline Ecuador & January 1996 & n.a. \\
\hline Guatemala & October 1991 & n.a. \\
\hline Guinea & December 1994 & n.a. \\
\hline Hungary & September 1973 & n.a. \\
\hline The Kyrgyz Republic & December 1998 & n.a. \\
\hline Mali & January 1993 & n.a. \\
\hline Mongolia & January 1997 & n.a. \\
\hline Morocco & June 1987 & n.a. \\
\hline Romania & November 1971 & n.a. \\
\hline
\end{tabular}

high-income economies had statistically significant increases in the growth rate of import and in the ratio of import to GDP. The increases were also economically significant: The increase in the growth rate of import is around 5 percent per year and from 0.79 percent to 1.04 percent per year in the percentage of import-GDP. In contrast, the findings about lowincome economies are mixed. Table 4.7 shows no statistically significant results on the selection and accession effects for low-income economies. Table 4.8 shows negative coefficients of the selection effect but positive ones for the accession effect.

Tables 4.9 and 4.10 show a general pattern of the impact of GATT/WTO accessions on economies of different legal institutions. Continental-law economies showed statistically and economically significant increases in 


\begin{tabular}{lcc}
\hline Country & Accession Year & Predicted Accession Year \\
\hline Algeria & Predicted to Join during 1960-1998 (12 economies) \\
Bhutan & n.a. & 1975 \\
Comoros & n.a. & 1981 \\
Equatorial Guinea & n.a. & 1981 \\
Estonia & n.a. & 1986 \\
Jordan & n.a. & 1993 \\
Lebanon & April 2000 & 1977 \\
Oman & n.a. & 1990 \\
Puerto Rico & November 2000 & 1969 \\
Saudi Arabia & n.a. & 1961 \\
Seychelles & n.a. & 1961 \\
Tonga & n.a. & 1977 \\
& n.a. & 1982 \\
Albania & Predicted Not to Join by 1998 (4 economies) & \\
China & September 2000 & n.a. \\
Kazakhstan & November 2001 & n.a. \\
Turkmenistan & n.a. & n.a. \\
\hline
\end{tabular}

Table 4.7 Regressions of Measures of Import with Income Dummies Using the Heckman and Hotz (1989) Method to Control for Selection Endogeneity

\begin{tabular}{lccc}
\hline & \multicolumn{3}{c}{ Dependent Variable } \\
\cline { 2 - 4 } & $\begin{array}{c}\text { Log(Import) } \\
\text { (U.S.\$) }\end{array}$ & $\begin{array}{c}\text { Log(Import) } \\
\text { (local constant currency) }\end{array}$ & $\begin{array}{c}\text { Import/GDP } \\
(\%)\end{array}$ \\
\hline Year · HighIncome & $0.052^{* * *}$ & $0.055^{* * *}$ & $0.12^{* * *}$ \\
& $(31.28)$ & $(33.36)$ & $(2.81)$ \\
Year · LowIncome & $0.039^{* * *}$ & $0.038^{* * *}$ & $0.47^{* * *}$ \\
Selection · HighIncome & $(35.70)$ & $(34.60)$ & $(16.06)$ \\
& 0.024 & 0.012 & $2.47^{* * *}$ \\
Selection · LowIncome & $(1.19)$ & $(0.60)$ & $(4.95)$ \\
& 0.0018 & 0.0062 & -0.28 \\
Accession · HighIncome & $(0.15)$ & $(0.53)$ & $(-0.89)$ \\
& $0.050^{* * *}$ & $0.046^{* * *}$ & $0.79^{* * *}$ \\
Accession - LowIncome & $(7.56)$ & $(7.36)$ & $(5.04)$ \\
Intercept & 0.0057 & 0.0053 & -0.057 \\
& $(1.28)$ & $(1.20)$ & $(-0.48)$ \\
$R^{2}$ & $-63.61^{* * *}$ & $-62.80^{* * *}$ & $657.04^{* * *}$ \\
No. of observations & $(-35.12)$ & $(-34.62)$ & $(-13.99)$ \\
\hline
\end{tabular}

Notes: $T$-statistics are in parentheses. HighIncome $=1$ if in 1987 the GDP/Population $>$ U.S. $\$ 3,000$; otherwise, LowIncome $=1$. Selection $=0$ until two years before GATT/WTO accession; Selection $=1,2,3,3,3, \ldots$ thereafter.

***Significant at the 1 percent level. 
Table 4.8

Regressions of Measures of Import with Income Dummies Using Predicted GATT/WTO Membership to Control for Selection Endogeneity

\begin{tabular}{|c|c|c|c|}
\hline & \multicolumn{3}{|c|}{ Dependent Variable } \\
\hline & $\begin{array}{l}\log (\text { Import }) \\
\quad(\text { U.S.\$) }\end{array}$ & $\begin{array}{c}\log (\text { Import }) \\
\text { (local constant currency) }\end{array}$ & $\begin{array}{c}\text { Import/GDP } \\
(\%)\end{array}$ \\
\hline \multirow[t]{2}{*}{ Year $\cdot$ HighIncome } & $0.041^{* * *}$ & $0.042^{* * *}$ & 0.083 \\
\hline & $(14.19)$ & $(14.25)$ & $(0.93)$ \\
\hline \multirow[t]{2}{*}{ Year $\cdot$ LowIncome } & $0.050 * * *$ & $0.049 * * *$ & $0.48 * * *$ \\
\hline & $(36.00)$ & $(35.19)$ & $(12.58)$ \\
\hline \multirow[t]{2}{*}{ Selection $\cdot$ HighIncome } & $0.016^{* * *}$ & $0.018 * * *$ & 0.081 \\
\hline & $(4.78)$ & $(5.31)$ & $(0.84)$ \\
\hline \multirow[t]{2}{*}{ Selection $\cdot$ LowIncome } & $-0.02 * * *$ & $-0.02 * * *$ & -0.039 \\
\hline & $(-11.16)$ & $(-11.11)$ & $(-0.79)$ \\
\hline \multirow[t]{2}{*}{ Accession $\cdot$ HighIncome } & $0.050 * * *$ & $0.044 * * *$ & $1.04 * * *$ \\
\hline & $(8.27)$ & $(7.66)$ & $(7.00)$ \\
\hline \multirow[t]{2}{*}{ Accession $\cdot$ LowIncome } & $0.0094 * *$ & $0.0097 * *$ & -0.080 \\
\hline & $(2.30)$ & $(2.36)$ & $(-0.70)$ \\
\hline \multirow[t]{2}{*}{ Intercept } & $-72.14 * * *$ & $-69.26 * * *$ & $650.50 * * *$ \\
\hline & $(-28.25)$ & $(-26.26)$ & $(-8.39)$ \\
\hline$R^{2}$ & 0.664 & 0.653 & 0.157 \\
\hline No. of observations & 2,855 & 3,067 & 3,398 \\
\hline
\end{tabular}

Notes: T-statistics are in parentheses. HighIncome $=1$ if in 1987 the GDP/Population $>$ U.S. $\$ 3,000$; otherwise, LowIncome $=1$. Selection $=0$ before predicted GATT/WTO accession; Selection $=1,2,3,4, \ldots$ thereafter.

*** Significant at the 1 percent level.

**Significant at the 5 percent level.

all three measures of import. The increase in the growth rate of import was around 3 percent per year and from 0.25 percent to 0.28 percent in the percentage of import to GDP. Common-law economies also had significant increase in import but mostly in the ratio of import to GDP. The increase in the import/GDP percentage was 0.25 percent or .037 percent, depending on the configuration of the regressions. As for the socialist economies, we found that the accession effect was negative in the ratio of import to GDP ratio, although the selection effect was positive. A robust result is the decrease around 1 percent or 1.5 percent per year after the accession in the percentage of import-GDP.

Tables 4.11 to 4.14 report regressions of the impact of GATT/WTO accessions on export. The regressions are of three alternative measures of export: export in constant U.S. dollars, export in constant local currency, and export-GDP, respectively. Similar to import-GDP, the ratio of export to GDP is often regarded as a measure of dependence of the economy on foreign markets as well as international competitiveness. 
Table 4.9

Regressions Measures of Import with Legal Origin Dummies Using the Heckman and Hotz (1989) Method to Control for Selection Endogeneity

\begin{tabular}{lccc}
\hline & \multicolumn{3}{c}{ Dependent Variable } \\
\cline { 2 - 4 } & $\begin{array}{l}\log (\text { Import }) \\
\text { (U.S.\$) }\end{array}$ & $\begin{array}{c}\text { Log(Import) } \\
\text { (local constant currency) }\end{array}$ & $\begin{array}{c}\text { Import/GDP } \\
(\%)\end{array}$ \\
\hline Year $\cdot$ CommonLaw & $0.039^{* * *}$ & $0.042^{* * *}$ & $0.41^{* * *}$ \\
Year $\cdot$ ContinentalLaw & $(22.48)$ & $(23.90)$ & $(9.58)$ \\
& $0.044^{* * *}$ & $0.043^{* * *}$ & $0.32^{* * *}$ \\
Year $\cdot$ Socialist & $(34.69)$ & $(34.18)$ & $(10.69)$ \\
& $0.058^{* * *}$ & $0.058^{* * *}$ & $0.67^{* * *}$ \\
Selection $\cdot$ CommonLaw & $(8.12)$ & $(8.02)$ & $(4.36)$ \\
& $0.037^{* *}$ & 0.029 & $0.89^{* *}$ \\
Selection $\cdot$ ContinentalLaw & $(2.06)$ & $(1.62)$ & $(2.13)$ \\
Selection $\cdot$ Socialist & -0.017 & -0.019 & -0.11 \\
& $(-1.14)$ & $(-1.29)$ & $(-0.30)$ \\
Accession $\cdot$ CommonLaw & $-0.32^{* * *}$ & $-0.32^{* * *}$ & $2.58^{* *}$ \\
Accession $\cdot$ ContinentalLaw & $(-6.65)$ & $(-6.57)$ & $(2.30)$ \\
& 0.0045 & 0.00025 & $0.27^{*}$ \\
Accession $\cdot$ Socialist & $(0.69)$ & $(0.004)$ & $(1.74)$ \\
& $0.028^{* * *}$ & $0.029^{* * *}$ & $0.25^{* *}$ \\
Intercept & $(5.18)$ & $(5.76)$ & $(1.96)$ \\
& -0.0040 & -0.0040 & $-0.97^{*}$ \\
$R^{2}$ & $(-0.18)$ & $(-0.18)$ & $(-1.85)$ \\
No. of observations & $-61.99^{* * *}$ & $-60.93^{* * *}$ & $-690.84^{* * *}$ \\
\hline & $(-30.41)$ & $(-30.02)$ & $(-14.21)$ \\
& 0.576 & 0.564 & 0.151 \\
& 2,855 & 3,067 & 3,398 \\
\hline
\end{tabular}

Notes: $T$-statistics are in parentheses. Selection $=0$ until two years before GATT/WTO accession; Selection $=1,2,3,3,3, \ldots$ thereafter.

***Significant at the 1 percent level.

**Significant at the 5 percent level.

*Significant at the 10 percent level.

From tables 4.11 and 4.12, we can see that the high-income economies had significant increases in the growth rate of export ( 3 percent to 5 percent per year) and in export-GDP (1.2 percent to 1.5 percent per year) due to the accession effect. Low-income economies also experienced increases in the growth rate of export, but the magnitude of increase, around 1 percent per year, is significantly smaller than that of the high-income counterparts. Moreover, there is some evidence (in one regression) that lowincome economies experienced slight decreases $(0.2$ percent a year $)$ in the ratio of export to GDP (table 4.12).

The results in tables 4.13 and 4.14 show that those continental-law economies enjoyed positive and significant accession effects in export. The growth of export increased by around 1 to 2 percent per year due to 
Table 4.10 Regressions of Measures of Import with Legal Origin Dummies Using Predicted GATT/WTO Membership to Control for

Selection Endogeneity

\begin{tabular}{|c|c|c|c|}
\hline & \multicolumn{3}{|c|}{ Dependent Variable } \\
\hline & $\begin{array}{l}\log (\text { Import }) \\
\text { (U.S.\$) }\end{array}$ & $\begin{array}{c}\log (\text { Import }) \\
\text { (local constant currency) }\end{array}$ & $\begin{array}{c}\text { Import/GDP } \\
(\%)\end{array}$ \\
\hline Year $\cdot$ CommonLaw & $\begin{array}{l}0.051^{* * *} \\
(13.73)\end{array}$ & $\begin{array}{l}0.052^{* * *} \\
(13.68)\end{array}$ & $\begin{array}{l}0.34 * * * \\
(2.88)\end{array}$ \\
\hline Year $\cdot$ ContinentalLaw & $\begin{array}{l}0.046^{* * *} \\
(28.49)\end{array}$ & $\begin{array}{l}0.045^{* * *} \\
(27.85)\end{array}$ & $\begin{array}{l}0.42^{* * *} \\
(10.84)\end{array}$ \\
\hline Year $\cdot$ Socialist & $\begin{array}{l}0.046^{* * *} \\
(6.65)\end{array}$ & $\begin{array}{l}0.046^{* * *} \\
(6.57)\end{array}$ & $\begin{array}{l}0.80^{* * *} \\
(5.45)\end{array}$ \\
\hline Selection $\cdot$ CommonLaw & $\begin{array}{l}-0.013^{* * *} \\
(-3.24)\end{array}$ & $\begin{array}{l}-0.011^{* * *} \\
(-2.70)\end{array}$ & $\begin{array}{c}0.11 \\
(0.94)\end{array}$ \\
\hline Selection $\cdot$ ContinentalLaw & $\begin{array}{l}-0.0059^{* * *} \\
(-2.59)\end{array}$ & $\begin{array}{l}-0.0050^{* *} \\
(-2.25)\end{array}$ & $\begin{array}{l}-0.22^{* * *} \\
(-4.04)\end{array}$ \\
\hline Selection $\cdot$ Socialist & $\begin{array}{l}0.093^{* * *} \\
(2.77)\end{array}$ & $\begin{array}{l}0.093^{* * *} \\
(2.74)\end{array}$ & $\begin{array}{l}2.44 * * * \\
(2.87)\end{array}$ \\
\hline Accession $\cdot$ CommonLaw & $\begin{array}{l}0.011^{*} \\
(1.75)\end{array}$ & $\begin{array}{l}0.0054 \\
(0.86)\end{array}$ & $\begin{array}{l}0.37^{* *} \\
(2.48)\end{array}$ \\
\hline Accession $\cdot$ ContinentalLaw & $\begin{array}{l}0.026^{* * *} \\
(5.15)\end{array}$ & $\begin{array}{l}0.028 * * * \\
(5.75)\end{array}$ & $\begin{array}{l}0.28 * * * \\
(2.37)\end{array}$ \\
\hline Accession $\cdot$ Socialist & $\begin{array}{l}-0.042^{*} \\
(-1.81)\end{array}$ & $\begin{array}{l}-0.042^{*} \\
(-1.79)\end{array}$ & $\begin{array}{l}-1.49^{* * *} \\
(2.65)\end{array}$ \\
\hline Intercept & $\begin{array}{l}-71.47 * * * \\
(-22.00)\end{array}$ & $\begin{array}{l}-68.75^{* * * *} \\
(-20.96)\end{array}$ & $\begin{array}{l}-770.57 * * * \\
(-8.07)\end{array}$ \\
\hline$R^{2}$ & 0.572 & 0.560 & 0.155 \\
\hline No. of observations & 2,855 & 3,067 & 3,398 \\
\hline
\end{tabular}

Notes: $T$-statistics are in parentheses. Selection $=0$ until two years before GATT/WTO accession; Selection $=1,2,3,4, \ldots$, thereafter.

*** Significant at the 1 percent level.

** Significant at the 5 percent level.

*Significant at the 10 percent level.

accession, and the export-GDP ratio increased by about 0.2 percent per year. The common-law economies showed mixed signs in changes in the growth rate of export but significant increases in export-GDP (around 0.5 percent to 0.7 percent per year). However, the socialist economies actually experienced decreases in export-GDP due to the accession effect in the magnitude of 0.7 percent to 0.9 percent per year, although the accession did seem to have chosen the faster-growing socialist economies in export.

Tables 4.15 to 4.18 list regressions of two alternative measures of FDI: $\log$ (FDI) and FDI-GDP ratio. Tables 4.15 and 4.16 are about the impact of GATT/WTO accession on high- and low-income economies. They show 


\begin{tabular}{lccc}
\hline & \multicolumn{3}{c}{ Dependent Variable } \\
\cline { 2 - 4 } & $\begin{array}{l}\text { Log(Import) } \\
\text { (U.S.\$) }\end{array}$ & $\begin{array}{c}\text { Log(Import) } \\
\text { (local constant currency) }\end{array}$ & $\begin{array}{c}\text { Import/GDP } \\
(\%)\end{array}$ \\
\hline Year · HighIncome & $0.059^{* * *}$ & $0.059^{* * *}$ & 0.029 \\
Year · LowIncome & $(35.88)$ & $(37.37)$ & $(0.82)$ \\
& $0.042^{* * *}$ & $0.042^{* *}$ & $0.29^{* * *}$ \\
Selection · HighIncome & $(39.35)$ & $(39.35)$ & $(11.71)$ \\
& $0.087^{* * *}$ & $0.10^{* * *}$ & $3.02^{* * *}$ \\
Selection · LowIncome & $(4.37)$ & $(5.28)$ & $(7.23)$ \\
& $0.024^{* * *}$ & $0.026^{* *}$ & $0.52^{* *}$ \\
Accession · HighIncome & $(2.06)$ & $(2.28)$ & $(1.98)$ \\
& $0.044^{* * *}$ & $0.033^{* * *}$ & $1.20^{* * *}$ \\
Accession · LowIncome & $(6.90)$ & $(5.62)$ & $(8.96)$ \\
& $0.0090^{* *}$ & $0.0087^{* *}$ & $-0.20^{* *}$ \\
Intercept & $(2.07)$ & $(2.07)$ & $(-1.98)$ \\
& $-71.79^{* * *}$ & $-70.19^{* * *}$ & $-369.82^{* * *}$ \\
$R^{2}$ & $(-40.59)$ & $(-40.41)$ & $(-9.27)$ \\
No. of observations & 0.705 & 0.697 & 0.161 \\
& 2,859 & 3,070 & 3,402 \\
\hline
\end{tabular}

Notes: See table 4.7.

***Significant at the 1 percent level.

**Significant at the 5 percent level.

Table 4.12 Regressions of Measures of Export with Income Dummies Using Predicted GATT/WTO Membership to Control for Selection Endogeneity

\begin{tabular}{lccc}
\hline & \multicolumn{3}{c}{ Dependent Variable } \\
\cline { 2 - 4 } & $\begin{array}{c}\text { Log(Import) } \\
\text { (U.S.\$) }\end{array}$ & $\begin{array}{c}\log (\text { Import) } \\
\text { (local constant currency) }\end{array}$ & $\begin{array}{c}\text { Import/GDP } \\
(\%)\end{array}$ \\
\hline Year· HighIncome & $0.062^{* * *}$ & $0.063^{* * *}$ & 0.012 \\
Year · LowIncome & $(21.45)$ & $(22.30)$ & $(0.16)$ \\
& $0.050^{* * *}$ & $0.050^{* * *}$ & $0.31^{* * *}$ \\
Selection · HighIncome & $(36.52)$ & $(36.64)$ & $(9.62)$ \\
Selection · LowIncome & -0.0030 & -0.0052 & 0.072 \\
& $(-0.90)$ & $(-1.61)$ & $(0.87)$ \\
Accession · HighIncome & $-0.014^{* * *}$ & $-0.014^{* * *}$ & -0.013 \\
& $(-7.83)$ & $(7.93)$ & $(-0.30)$ \\
Accession · LowIncome & $0.054^{* * *}$ & $0.045^{* * *}$ & $1.51^{* * *}$ \\
Intercept & $(9.13)$ & $(8.04)$ & $(11.85)$ \\
& $0.014^{* * *}$ & $0.014^{* * *}$ & -0.13 \\
$R^{2}$ & $(3.47)$ & $(3.54)$ & $(-1.36)$ \\
No. of observations & $-85.03^{* * *}$ & $-84.47^{* * *}$ & $-388.69^{* * *}$ \\
& $(-33.44)$ & $(-32.79)$ & $(-5.87)$ \\
& 0.709 & 0.700 & 0.147 \\
& 2,859 & 3,070 & 3,402 \\
\hline
\end{tabular}

Notes: See table 4.8.

***Significant at the 1 percent level. 
Table 4.13

Regressions of Measures of Export with Legal Origin Dummies Using the Heckman and Hotz (1989) Method to Control for

Selection Endogeneity

\begin{tabular}{|c|c|c|c|}
\hline & \multicolumn{3}{|c|}{ Dependent Variable } \\
\hline & $\begin{array}{l}\log (\text { Import }) \\
\text { (U.S.\$) }\end{array}$ & $\begin{array}{c}\log (\mathrm{Import}) \\
\text { (local constant currency) }\end{array}$ & $\begin{array}{c}\text { Import/GDP } \\
(\%)\end{array}$ \\
\hline Year $\cdot$ CommonLaw & $\begin{array}{l}0.045^{* * *} \\
(25.03)\end{array}$ & $\begin{array}{l}0.046^{* * * *} \\
(26.47)\end{array}$ & $\begin{array}{l}0.24 * * * \\
(6.41)\end{array}$ \\
\hline Year $\cdot$ ContinentalLaw & $\begin{array}{l}0.047^{* * * *} \\
(36.67)\end{array}$ & $\begin{array}{l}0.046^{* * * *} \\
(37.09)\end{array}$ & $\begin{array}{l}0.18^{* * * *} \\
(7.28)\end{array}$ \\
\hline Year $\cdot$ Socialist & $\begin{array}{l}0.064^{* * *} \\
(8.75)\end{array}$ & $\begin{array}{l}0.064^{* * *} \\
(8.89)\end{array}$ & $\begin{array}{l}0.44^{* * * *} \\
(3.31)\end{array}$ \\
\hline Selection $\cdot$ CommonLaw & $\begin{array}{l}0.085^{* * *} \\
(4.66)\end{array}$ & $\begin{array}{l}0.081 * * * \\
(4.53)\end{array}$ & $\begin{array}{l}1.95^{* * * *} \\
(5.49)\end{array}$ \\
\hline Selection $\cdot$ ContinentalLaw & $\begin{array}{l}-0.0024 \\
(-0.16)\end{array}$ & $\begin{array}{l}0.0076 \\
(0.53)\end{array}$ & $\begin{array}{l}0.017 \\
(0.06)\end{array}$ \\
\hline Selection $\cdot$ Socialist & $\begin{array}{l}-0.28 * * * \\
(-5.59)\end{array}$ & $\begin{array}{l}-0.28^{* * *} \\
(-5.68)\end{array}$ & $\begin{array}{l}4.23^{* * * *} \\
(4.42)\end{array}$ \\
\hline Accession $\cdot$ CommonLaw & $\begin{array}{l}0.000095 \\
(0.01)\end{array}$ & $\begin{array}{l}-0.0019 \\
(-0.29)\end{array}$ & $\begin{array}{l}0.51^{* * * *} \\
(3.87)\end{array}$ \\
\hline Accession $\cdot$ ContinentalLaw & $\begin{array}{l}0.027^{* * *} \\
(5.03)\end{array}$ & $\begin{array}{l}0.023^{* * * *} \\
(4.59)\end{array}$ & $\begin{array}{c}0.20^{*} \\
(1.82)\end{array}$ \\
\hline Accession $\cdot$ Socialist & $\begin{array}{l}0.0017 \\
(0.08)\end{array}$ & $\begin{array}{l}0.0017 \\
(0.08)\end{array}$ & $\begin{array}{l}-0.77^{*} \\
(-1.72)\end{array}$ \\
\hline Intercept & $\begin{array}{l}-70.23 * * * \\
(-33.90)\end{array}$ & $\begin{array}{l}-68.13^{* * *} \\
(-33.94)\end{array}$ & $\begin{array}{l}-394.12 * * * \\
(-9.49)\end{array}$ \\
\hline$R^{2}$ & 0.617 & 0.613 & 0.138 \\
\hline No. of observations & 2,859 & 3,070 & 3,402 \\
\hline
\end{tabular}

Notes: See table 4.9.

*** Significant at the 1 percent level.

*Significant at the 10 percent level.

that both the high-income group and the low-income group had statistically significant and positive increases in $\log (\mathrm{FDI})$ due to the accession effect, while the high-income group saw much bigger increases than the low-income group ( 12 to 13 percent vs. 7 to 9 percent per year). Moreover, there is no strong evidence that the FDI-GDP ratio significantly increased due to the accession effect for both income groups (only one out of four regressions shows statistically positive changes).

One robust finding across regressions in tables 4.17 and 4.18 is that the continental-law economies had drastic upward shifts (around 15 or 16 percent) in $\log (\mathrm{FDI})$ due to accession. There is weak evidence that the common-law economies had a higher FDI-GDP ratio due to the accession effect. The former socialist economies did not show any significant changes in either $\log (\mathrm{FDI})$ or FDI-GDP due to accession. 
Table 4.14 Regressions of Measures of Export with Legal Origin Dummies Using Predicted GATT/WTO Membership to Control for Selection Endogeneity

\begin{tabular}{lccc}
\hline & \multicolumn{3}{c}{ Dependent Variable } \\
\cline { 2 - 4 } & $\begin{array}{l}\text { Log(Import) } \\
\text { (U.S.\$) }\end{array}$ & $\begin{array}{c}\text { Log(Import) } \\
\text { (local constant currency) }\end{array}$ & $\begin{array}{c}\text { Import/GDP } \\
(\%)\end{array}$ \\
\hline Year $\cdot$ CommonLaw & $0.062^{* * *}$ & $0.062^{* * *}$ & 0.093 \\
Year $\cdot$ ContinentalLaw & $(16.31)$ & $(16.66)$ & $(0.92)$ \\
& $0.049^{* * *}$ & $0.049^{* * *}$ & $0.27^{* * *}$ \\
Year $\cdot$ Socialist & $(30.00)$ & $(31.03)$ & $(8.21)$ \\
& $0.053^{* * *}$ & $0.053^{* * *}$ & $0.63^{* * *}$ \\
Selection $\cdot$ CommonLaw & $(7.53)$ & $(7.65)$ & $(4.97)$ \\
& $-0.018^{* * *}$ & $-0.017^{* * *}$ & $0.23^{* *}$ \\
Selection $\cdot$ ContinentalLaw & $(-4.39)$ & $(-4.25)$ & $(2.18)$ \\
Selection $\cdot$ Socialist & $-0.0052^{* *}$ & $-0.0065^{* * *}$ & $-0.18^{* * *}$ \\
& $(-2.23)$ & $(-2.94)$ & $(-3.94)$ \\
Accession $\cdot$ CommonLaw & 0.038 & 0.038 & 1.04 \\
& $(1.11)$ & $(1.12)$ & $(1.42)$ \\
Accession $\cdot$ ContinentalLaw & $0.013^{* *}$ & $0.010^{*}$ & $0.73^{* * *}$ \\
& $(2.01)$ & $(1.65)$ & $(5.73)$ \\
Accession $\cdot$ Socialist & $0.028^{* * *}$ & $0.025^{* * *}$ & $0.24^{* *}$ \\
& $(5.33)$ & $(5.15)$ & $(2.31)$ \\
Intercept & -0.020 & -0.020 & $-0.89^{*}$ \\
& $(-0.85)$ & $(-0.86)$ & $(-1.84)$ \\
$R^{2}$ & $-83.62^{* * *}$ & $-82.16^{* * *}$ & $-416.40^{* * *}$ \\
No. of observations & $(-25.32)$ & $(-25.36)$ & $(-5.08)$ \\
\hline & 0.613 & 0.610 & 0.131 \\
& 2,859 & 3,070 & 3,402 \\
\hline
\end{tabular}

Notes: See table 4.10.

***Significant at the 1 percent level.

**Significant at the 5 percent level.

*Significant at the 10 percent level.

\subsubsection{Impact on Gross Domestic Product Growth}

Tables 4.19 and 4.20 report the regression results on the impact of accession on the growth rate of GDP, using the Heckman and Hotz (1989) method and the predicted accession approach to control for the selection effect. The two tables show consistent results. Classified by income level, economies with high per capita income experienced positive and statistically significant increase in their GDP growth after the accession. The impact was around 1.5 percent and 1.6 percent increase in the GDP growth rate per year for the ten years after accession. For low-income countries, we cannot find any statistically significant changes in GDP growth after GATT/WTO accession. The two tables also show conflicting evidence on the selection effect for low-income economies. For the high-income group, 


\begin{tabular}{|c|c|c|}
\hline & \multicolumn{2}{|c|}{ Dependent Variable } \\
\hline & $\log (\mathrm{FDI})(\mathrm{U} . \mathrm{S} . \$)$ & FDI/GDP $(\%)$ \\
\hline Year $\cdot$ HighIncome & $\begin{array}{l}0.096^{* * *} \\
(15.70)\end{array}$ & $\begin{array}{l}0.074 * * * \\
(3.46)\end{array}$ \\
\hline Year $\cdot$ LowIncome & $\begin{array}{l}0.080^{* * *} \\
(18.70)\end{array}$ & $\begin{array}{l}0.099^{* * * *} \\
(6.81)\end{array}$ \\
\hline Selection $\cdot$ HighIncome & $\begin{array}{c}0.043 \\
(0.47)\end{array}$ & $\begin{array}{c}0.33 \\
(1.09)\end{array}$ \\
\hline Selection · LowIncome & $\begin{array}{r}0.057 \\
(1.44)\end{array}$ & $\begin{array}{c}0.20 \\
(1.42)\end{array}$ \\
\hline Accession $\cdot$ HighIncome & $\begin{array}{l}0.12 * * * \\
(3.63)\end{array}$ & $\begin{array}{c}0.068 \\
(0.61)\end{array}$ \\
\hline Accession $\cdot$ LowIncome & $\begin{array}{l}0.077^{* * *} \\
(4.19)\end{array}$ & $\begin{array}{r}0.091 \\
(1.49)\end{array}$ \\
\hline Intercept & $\begin{array}{l}-151.69^{* * *} \\
(-21.82)\end{array}$ & $\begin{array}{c}-180.26^{* * * *} \\
(-7.61)\end{array}$ \\
\hline$R^{2}$ & 0.367 & 0.0546 \\
\hline No. of observations & 2,132 & 2,606 \\
\hline
\end{tabular}

Notes: See table 4.7.

*** Significant at the 1 percent level.

Table 4.16 Regressions of Measures of FDI on Income Dummies Using Predicted GATT/WTO Membership to Control for Selection Endogeneity

\begin{tabular}{|c|c|c|}
\hline & \multicolumn{2}{|c|}{ Dependent Variable } \\
\hline & $\log (\mathrm{FDI})(\mathrm{U} . \mathrm{S} . \$)$ & FDI/GDP $(\%)$ \\
\hline Year $\cdot$ HighIncome & $\begin{array}{l}0.096^{* * *} \\
(6.21)\end{array}$ & $\begin{array}{l}0.15^{* * *} \\
(2.97)\end{array}$ \\
\hline Year $\cdot$ LowIncome & $\begin{array}{l}0.097^{* * *} \\
(15.15)\end{array}$ & $\begin{array}{l}0.063^{* * * *} \\
(2.94)\end{array}$ \\
\hline Selection $\cdot$ HighIncome & $\begin{array}{l}0.0047 \\
(0.03)\end{array}$ & $\begin{array}{l}-0.089 \\
(-1.62)\end{array}$ \\
\hline Selection $\cdot$ LowIncome & $\begin{array}{l}-0.023^{* * *} \\
(-2.92)\end{array}$ & $\begin{array}{l}0.069^{* * *} \\
(2.61)\end{array}$ \\
\hline Accession $\cdot$ HighIncome & $\begin{array}{l}0.13 * * * \\
(4.10)\end{array}$ & $\begin{array}{r}0.053 \\
(0.48)\end{array}$ \\
\hline Accession $\cdot$ LowIncome & $\begin{array}{l}0.090^{* * * *} \\
(5.28)\end{array}$ & $\begin{array}{l}0.12^{* *} \\
(2.11)\end{array}$ \\
\hline Intercept & $\begin{array}{l}-174.06^{* * * *} \\
(-13.60)\end{array}$ & $\begin{array}{c}-176.89^{* * *} \\
(-4.18)\end{array}$ \\
\hline$R^{2}$ & 0.369 & 0.0570 \\
\hline No. of observations & 2,132 & 2,606 \\
\hline
\end{tabular}

Notes: See table 4.8.

*** Significant at the 1 percent level.

**Significant at the 5 percent level. 
Table 4.17

Regressions of Measures of FDI with Legal Origin Dummies Using the Heckman and Hotz (1989) Method to Control for Selection Endogeneity

\begin{tabular}{|c|c|c|}
\hline & \multicolumn{2}{|c|}{ Dependent Variable } \\
\hline & Log(FDI) (U.S.\$) & FDI/GDP $(\%)$ \\
\hline Year $\cdot$ CommonLaw & $\begin{array}{l}0.10^{* * * *} \\
(17.49)\end{array}$ & $\begin{array}{l}0.11 * * * \\
(5.22)\end{array}$ \\
\hline Year $\cdot$ ContinentalLaw & $\begin{array}{l}0.071^{* * *} \\
(16.27)\end{array}$ & $\begin{array}{l}0.074 * * * \\
(4.85)\end{array}$ \\
\hline Year $\cdot$ Socialist & $\begin{array}{l}0.27^{* * * *} \\
(7.09)\end{array}$ & $\begin{array}{l}0.25^{* * * *} \\
(3.82)\end{array}$ \\
\hline Selection $\cdot$ CommonLaw & $\begin{array}{l}-0.015 \\
(-0.25)\end{array}$ & $\begin{array}{c}0.45^{* *} \\
(2.25)\end{array}$ \\
\hline Selection $\cdot$ ContinentalLaw & $\begin{array}{c}0.032 \\
(0.68)\end{array}$ & $\begin{array}{c}0.11 \\
(0.64)\end{array}$ \\
\hline Selection $\cdot$ Socialist & $\begin{array}{c}0.18 \\
(1.09)\end{array}$ & $\begin{array}{c}0.19 \\
(0.40)\end{array}$ \\
\hline Accession $\cdot$ CommonLaw & $\begin{array}{l}0.0084 \\
(0.34)\end{array}$ & $\begin{array}{c}0.094 \\
(1.16)\end{array}$ \\
\hline Accession $\cdot$ ContinentalLaw & $\begin{array}{l}0.15^{* * *} \\
(7.04)\end{array}$ & $\begin{array}{c}0.072 \\
(0.92)\end{array}$ \\
\hline Accession $\cdot$ Socialist & $\begin{array}{l}-0.094 \\
(-0.86)\end{array}$ & $\begin{array}{l}-0.14 \\
(-0.66)\end{array}$ \\
\hline Intercept & $\begin{array}{l}-167.22^{* * * *} \\
(-21.62)\end{array}$ & $\begin{array}{c}-191.62 * * * \\
(7.98)\end{array}$ \\
\hline$R^{2}$ & 0.374 & 0.060 \\
\hline No. of observations & 2,132 & 2,606 \\
\hline
\end{tabular}

Notes: See table 4.9.

$* * *$ Significant at the 1 percent level.

**Significant at the 5 percent level.

table 4.20 shows a positive selection effect: that is, high-income economies qualified for GATT/WTO membership had a 1.1 percent increase in GDP growth, besides an 1.5 percent to 1.6 percent increase in GDP growth after the actual accession.

As for the differences among economies of different legal institutions in responding to GATT/WTO accessions, table 4.20 shows that the commonlaw economies in the sample experienced, on average, a 1 percent increase in GDP growth after their accession to GATT/WTO, while socialist economies had a decrease of about 2 percent in GDP growth. Both are statistically significant. However, the same pattern is not present in table 4.19, which is based on the Hechman and Hotz (1989) method and controlling for endogeneity of the accessions. One may summarize that there is some evidence that the common-law economies' growth rate benefited from 
Table 4.18

Regressions of Measures of FDI with Legal Origin Dummies Using Predicted GATT/WTO Membership to Control for Selection Endogeneity

\begin{tabular}{|c|c|c|}
\hline & \multicolumn{2}{|c|}{ Dependent Variable } \\
\hline & $\log (\mathrm{FDI})(\mathrm{U} . \mathrm{S} . \$)$ & FDI/GDP $(\%)$ \\
\hline Year $\cdot$ CommonLaw & $\begin{array}{l}0.17^{* * * *} \\
(9.88)\end{array}$ & $\begin{array}{c}0.055 \\
(1.09)\end{array}$ \\
\hline Year $\cdot$ ContinentalLaw & $\begin{array}{l}0.073^{* * *} \\
(11.07)\end{array}$ & $\begin{array}{l}0.062^{* * * *} \\
(2.63)\end{array}$ \\
\hline Year $\cdot$ Socialist & $\begin{array}{l}0.29 * * * \\
(8.06)\end{array}$ & $\begin{array}{l}0.26^{* * *} \\
(4.07)\end{array}$ \\
\hline Selection $\cdot$ CommonLaw & $\begin{array}{l}-0.081^{* * * *} \\
(-4.20)\end{array}$ & $\begin{array}{r}0.076 \\
(1.38)\end{array}$ \\
\hline Selection $\cdot$ ContinentalLaw & $\begin{array}{l}-0.0016 \\
(-0.19)\end{array}$ & $\begin{array}{c}0.023 \\
(0.78)\end{array}$ \\
\hline Selection $\cdot$ Socialist & $\begin{array}{l}-0.18 \\
(-1.24)\end{array}$ & $\begin{array}{c}0.35 \\
(1.12)\end{array}$ \\
\hline Accession $\cdot$ CommonLaw & $\begin{array}{c}0.028 \\
(1.18)\end{array}$ & $\begin{array}{l}0.154^{* *} \\
(2.02)\end{array}$ \\
\hline Accession $\cdot$ ContinentalLaw & $\begin{array}{l}0.16^{* * *} \\
(8.10)\end{array}$ & $\begin{array}{c}0.10 \\
(1.42)\end{array}$ \\
\hline Accession $\cdot$ Socialist & $\begin{array}{c}0.080 \\
(0.48)\end{array}$ & $\begin{array}{c}-0.21 \\
(-0.96)\end{array}$ \\
\hline Intercept & $\begin{array}{l}-219.06^{* * *} \\
(-14.80)\end{array}$ & $\begin{array}{c}-143.76^{* * *} \\
(-3.16)\end{array}$ \\
\hline$R^{2}$ & 0.379 & 0.059 \\
\hline No. of observations & 2,132 & 2,606 \\
\hline
\end{tabular}

Notes: See table 4.10.

***Significant at the 1 percent level.

**Significant at the 5 percent level.

GATT/WTO accession but that the socialist economies actually suffered in GDP growth.

\subsubsection{Impact on Total Factor Productivity}

Tables 4.21 to 4.24 list results of a set of production function regressions. The purpose is to study how the accessions affected the economies' TFP, which is the residual term in an economy's aggregate production function. Regressions in tables 4.21 and 4.22 use dummies for per capita income. Those in tables 4.23 and 4.24 use dummies for the economies' legal institutions.

The first regressions of tables 4.21 and 4.22 indicate that the high-income economies did experience a statistically significant increase in TFP growth in the amount of 1 percent per year due to the accession effect, while there 
Table 4.19

Regressions on Log(GDP) Using the Heckman and Hotz (1989) Method to Control for Selection Endogeneity

\begin{tabular}{|c|c|c|c|}
\hline & $\log (G D P)$ & & $\log (\mathrm{GDP})$ \\
\hline Year $\cdot$ HighIncome & $\begin{array}{l}0.039 * * * \\
(45.99)\end{array}$ & Year $\cdot$ CommonLaw & $\begin{array}{l}0.040^{* * * *} \\
(43.70)\end{array}$ \\
\hline Year $\cdot$ LowIncome & $\begin{array}{l}0.038^{* * * *} \\
(59.32)\end{array}$ & Year $\cdot$ ContinentalLaw & $\begin{array}{l}0.037^{* * * *} \\
(54.47)\end{array}$ \\
\hline Selection $\cdot$ HighIncome & $\begin{array}{c}0.011 \\
(1.12)\end{array}$ & Year $\cdot$ Socialist & $\begin{array}{l}0.039^{* * *} \\
(14.71)\end{array}$ \\
\hline Selection $\cdot$ LowIncome & $\begin{array}{l}0.013^{*} \\
(1.88)\end{array}$ & Selection $\cdot$ CommonLaw & $\begin{array}{l}0.051^{* * *} \\
(5.58)\end{array}$ \\
\hline Accession $\cdot$ HighIncome & $\begin{array}{l}0.016^{* * * *} \\
(4.75)\end{array}$ & Selection $\cdot$ ContinentalLaw & $\begin{array}{l}-0.013 \\
(-1.55)\end{array}$ \\
\hline Accession $\cdot$ LowIncome & $\begin{array}{l}-0.0024 \\
(-0.92)\end{array}$ & Selection $\cdot$ Socialist & $\begin{array}{l}-0.099 \\
(-4.46)\end{array}$ \\
\hline Intercept & $\begin{array}{l}-51.40 * * * \\
(-50.97)\end{array}$ & $\begin{array}{l}\text { Accession } \cdot \text { CommonLaw } \\
\text { Accession } \cdot \text { Continetal } \\
\text { Accession } \cdot \text { Socialist } \\
\text { Intercept }\end{array}$ & $\begin{array}{c}0.0045 \\
(1.28) \\
0.0016 \\
(0.55) \\
-0.013 \\
(-1.21) \\
-50.54 * * * \\
(-47.53)\end{array}$ \\
\hline$R^{2}$ & 0.757 & $R^{2}$ & 0.735 \\
\hline No. of observations & 3,647 & No. of observations & 3,647 \\
\hline
\end{tabular}

Notes: See table 4.7.

***Significant at the 1 percent level.

*Significant at the 10 percent level.

is some evidence (the first regression in table 4.22 but not in table 4.21 ) that the low-income economies' TFP growth also increased by 0.5 percent per year. More interestingly, in the regressions where we control for the indirect effects of accession via import, export, and FDI, the net effects of accession on TFP growth for low-income economies are statistically significant and positive (1 percent per year) and slightly negative for high-income economies. This shows that the low-income economies did benefit in terms of higher economic efficiency through the intangible influences of accession to GATT/WTO (rather than through the tangible changes in import, export, and FDI).

From tables 4.23 and 4.24 , we can see that there is weak evidence that both the common-law economy group and the continental-law group experienced positive accession effects in TFP growth. The magnitude of TFP increase per year due to GATT/WTO accessions is around 0.5 percent. It is weak rather than strong evidence because some regressions have statistically significant TFP increase but others have insignificant results. Perhaps a more interesting finding is that the socialist accession economies 
Table 4.20

Regressions of $\log ($ GDP) Using Predicted GATT/WTO Membership to Control for Selection Endogeneity

\begin{tabular}{|c|c|c|c|}
\hline & $\log (\mathrm{GDP})$ & & $\log (\mathrm{GDP})$ \\
\hline Year $\cdot$ HighIncome & $\begin{array}{l}0.032^{* * * *} \\
(19.81)\end{array}$ & Year $\cdot$ CommonLaw & $\begin{array}{l}0.040 * * * \\
(21.99)\end{array}$ \\
\hline Year $\cdot$ LowIncome & $\begin{array}{l}0.040^{* * *} \\
(49.85)\end{array}$ & Year $\cdot$ ContinentalLaw & $\begin{array}{l}0.040^{* * *} \\
(44.04)\end{array}$ \\
\hline Selection $\cdot$ HighIncome & $\begin{array}{r}0.011 \\
(5.85)\end{array}$ & Year $\cdot$ Socialist & $\begin{array}{l}0.036^{* * * *} \\
(14.08)\end{array}$ \\
\hline Selection $\cdot$ LowIncome & $\begin{array}{l}-0.044^{* * * *} \\
(-3.97)\end{array}$ & Selection $\cdot$ CommonLaw & $\begin{array}{c}0.029 \\
(1.43)\end{array}$ \\
\hline Accession $\cdot$ HighIncome & $\begin{array}{l}0.016^{* * *} \\
(5.18)\end{array}$ & Selection $\cdot$ ContinentalLaw & $\begin{array}{l}-0.0069 * * * \\
(-5.45)\end{array}$ \\
\hline Accession $\cdot$ LowIncome & $\begin{array}{l}-0.0046 \\
(-0.92)\end{array}$ & Selection $\cdot$ Socialist & $\begin{array}{l}-0.044^{* *} \\
(-2.54)\end{array}$ \\
\hline Intercept & $\begin{array}{l}-49.39^{* * *} \\
(-32.69)\end{array}$ & $\begin{array}{l}\text { Accession } \cdot \text { CommonLaw } \\
\text { Accession } \cdot \text { Continetal } \\
\text { Accession } \cdot \text { Socialist } \\
\text { Intercept }\end{array}$ & $\begin{array}{l}0.010^{* * *} \\
(3.06) \\
0.0011 \\
(0.40) \\
-0.021^{* *} \\
(-2.13) \\
-53.03 * * * \\
(-47.53)\end{array}$ \\
\hline$R^{2}$ & 0.760 & $R^{2}$ & 0.733 \\
\hline No. of observations & 3,647 & No. of observations & 3,647 \\
\hline
\end{tabular}

Notes: See table 4.8.

*** Significant at the 1 percent level.

**Significant at the 5 percent level.

had no positive increases in TFP due to the accession effect. In fact, after separating the indirect effects via import, export, and FDI, we find that the direct effect of accession on TFP growth was about -1.1 percent per year.

\subsubsection{Summary and Interpretation of the Findings}

Overall, the findings of our regressions can be summarized in two parts.

First, in terms of engaging more international trade and attracting more FDI, both the high-income and low-income groups made significant progress, with the high-income group having much more gains than the other group. In this regard, both the common-law country group and the continental-law group saw significant increase, while the former socialist economies had either insignificant or mixed changes due to the accessions.

Second, with regard to changes in the growth rate of the economywide TFP, the high-income group and the common-law as well as continentallaw economies saw significant increases due to their accessions to GATT/ WTO. The low-income group and the former socialist economies had ei- 
Table 4.21 Production Function Regressions with Income Dummies Using the Heckman and Hotz (1989) Method to Control for Selection Endogeneity

\begin{tabular}{|c|c|c|}
\hline & \multicolumn{2}{|c|}{ Dependent Variable } \\
\hline & $\log (\mathrm{GDP})$ & $\log (\mathrm{GDP})$ \\
\hline Year $\cdot$ HighIncome & $\begin{array}{l}0.023 * * * \\
(21.19)\end{array}$ & $\begin{array}{l}0.0082^{* * * *} \\
(6.26)\end{array}$ \\
\hline Year $\cdot$ LowIncome & $\begin{array}{l}0.0065^{* * *} \\
(3.98)\end{array}$ & $\begin{array}{l}0.0031^{*} \\
(1.87)\end{array}$ \\
\hline $\log ($ Capital $) \cdot$ HighIncome & $\begin{array}{l}0.59^{* * * *} \\
(30.00)\end{array}$ & $\begin{array}{l}0.588^{* * *} \\
(20.91)\end{array}$ \\
\hline $\log ($ Capital $) \cdot$ LowIncome & $\begin{array}{l}0.58^{* * * *} \\
(35.85)\end{array}$ & $\begin{array}{c}0.60 * * * \\
(42.29)\end{array}$ \\
\hline $\log ($ Labor $) \cdot$ HighIncome & $\begin{array}{c}0.022 \\
(0.58)\end{array}$ & $\begin{array}{l}0.40^{* * *} \\
(7.28)\end{array}$ \\
\hline $\log ($ Labor $) \cdot$ LowIncome & $\begin{array}{l}0.66^{* * * *} \\
(11.28)\end{array}$ & $\begin{array}{l}0.43^{* * * *} \\
(7.60)\end{array}$ \\
\hline Selection $\cdot$ HighIncome & $\begin{array}{l}0.0023 \\
(0.26)\end{array}$ & $\begin{array}{l}-0.046^{* * *} \\
(-3.69)\end{array}$ \\
\hline Selection $\cdot$ LowIncome & $\begin{array}{l}-0.0070 \\
(-1.28)\end{array}$ & $\begin{array}{l}-0.0031 \\
(-0.69)\end{array}$ \\
\hline Accession $\cdot$ HighIncome & $\begin{array}{l}0.010^{* * *} \\
(3.53)\end{array}$ & $\begin{array}{l}-0.0063^{*} \\
(-1.71)\end{array}$ \\
\hline Accession $\cdot$ LowIncome & $\begin{array}{l}0.0033 \\
(1.61)\end{array}$ & $\begin{array}{l}0.010^{* * *} \\
(5.43)\end{array}$ \\
\hline Import/GDP & & $\begin{array}{l}-0.0033^{* * *} \\
(-8.74)\end{array}$ \\
\hline Export/GDP & & $\begin{array}{l}0.0061^{* * * *} \\
(14.36)\end{array}$ \\
\hline FDI/GDP & & $\begin{array}{l}-0.00026 \\
(-0.37)\end{array}$ \\
\hline Intercept & $\begin{array}{l}-20.24 * * * \\
(-11.95)\end{array}$ & $\begin{array}{l}-5.76^{* * *} \\
(-3.17)\end{array}$ \\
\hline$R^{2}$ & 0.865 & 0.867 \\
\hline No. of observations & 3,377 & 2,304 \\
\hline
\end{tabular}

Notes: See table 4.7.

***Significant at the 1 percent level.

*Significant at the 10 percent level.

ther insignificant or even slightly negative changes in their productivity due to the accessions.

The findings lend themselves to easy interpretations. Economic backwardness, as indexed by low per capita income, did not seem to be an important positive factor enabling an economy to benefit from joining GATT/WTO. Initial economic institutions before joining international organizations are shown to be much more important. Economies with proper initial economic institutions are positioned to benefit most from 
Table 4.22

Production Function Regressions with Income Dummies Using Predicted GATT/WTO Membership to Control for Selection Endogeneity

\begin{tabular}{|c|c|c|}
\hline & \multicolumn{2}{|c|}{ Dependent Variable } \\
\hline & $\log (G D P)$ & $\log ($ GDP $)$ \\
\hline Year $\cdot$ HighIncome & $\begin{array}{l}0.020^{* * *} \\
(13.23)\end{array}$ & $\begin{array}{l}0.00037^{*} \\
(1.81)\end{array}$ \\
\hline Year $\cdot$ LowIncome & $\begin{array}{l}0.0071^{* * * *} \\
(4.38)\end{array}$ & $\begin{array}{l}0.0031 * \\
(1.89)\end{array}$ \\
\hline $\log ($ Capital $) \cdot$ HighIncome & $\begin{array}{c}0.59 * * * \\
(29.91)\end{array}$ & $\begin{array}{c}0.61^{* * * *} \\
(22.54)\end{array}$ \\
\hline $\log ($ Capital $) \cdot$ LowIncome & $\begin{array}{l}0.58^{* * * *} \\
(36.30)\end{array}$ & $\begin{array}{l}0.60^{* * *} \\
(41.71)\end{array}$ \\
\hline $\log ($ Labor $) \cdot$ HighIncome & $\begin{array}{c}0.019 \\
(0.52)\end{array}$ & $\begin{array}{l}0.32 * * * \\
(6.35)\end{array}$ \\
\hline $\log ($ Labor $) \cdot$ LowIncome & $\begin{array}{l}0.75^{* * *} \\
(12.77)\end{array}$ & $\begin{array}{l}0.44 * * * \\
(7.49)\end{array}$ \\
\hline Selection $\cdot$ HighIncome & $\begin{array}{l}0.0042^{* * *} \\
(2.93)\end{array}$ & $\begin{array}{l}0.0056^{* * *} \\
(3.06)\end{array}$ \\
\hline Selection $\cdot$ LowIncome & $\begin{array}{l}-0.0068 * * * \\
(-7.84)\end{array}$ & $\begin{array}{l}-0.00066 \\
(-0.75)\end{array}$ \\
\hline Accession $\cdot$ HighIncome & $\begin{array}{l}0.010^{* * * *} \\
(3.89)\end{array}$ & $\begin{array}{l}-0.0077^{* *} \\
(-2.14)\end{array}$ \\
\hline Accession $\cdot$ LowIncome & $\begin{array}{l}0.0046^{* *} \\
(2.35)\end{array}$ & $\begin{array}{l}0.010^{* * *} \\
(5.35)\end{array}$ \\
\hline Import/GDP & & $\begin{array}{l}-0.0033 * * * \\
(-8.70)\end{array}$ \\
\hline Export/GDP & & $\begin{array}{l}0.0060^{* * *} \\
(14.03)\end{array}$ \\
\hline FDI/GDP & & $\begin{array}{l}-0.00019 \\
(-0.27)\end{array}$ \\
\hline Intercept & $\begin{array}{l}-19.86^{* * * *} \\
(-10.84)\end{array}$ & $\begin{array}{l}-3.26 \\
(-1.59)\end{array}$ \\
\hline$R^{2}$ & 0.868 & 0.867 \\
\hline No. of observations & 3,377 & 2,304 \\
\hline
\end{tabular}

Notes: See table 4.8.

***:Significant at the 1 percent level.

**Significant at the 5 percent level.

* Significant at the 10 percent level.

joining GATT/WTO. Countries with inefficient institutions such as the socialist economic system were found to benefit little, if not negatively, from the accession.

\subsection{Concluding Remarks}

In the spirit of event study, we put together a large panel data set with over 112 economies covering the years from 1960 to 1998. Seventy-four of 


\begin{tabular}{|c|c|c|}
\hline & \multicolumn{2}{|c|}{ Dependent Variable } \\
\hline & $\log (G D P)$ & $\log (G D P)$ \\
\hline Year $\cdot$ CommonLaw & $\begin{array}{c}0.018^{* * * *} \\
(17.26)\end{array}$ & $\begin{array}{l}0.0091^{* * * *} \\
(7.82)\end{array}$ \\
\hline Year $\cdot$ ContinentalLaw & $\begin{array}{l}0.019^{* * * *} \\
(50.61)\end{array}$ & $\begin{array}{l}0.0052 * * * \\
(4.79)\end{array}$ \\
\hline Year $\cdot$ Socialist & $\begin{array}{l}0.0092 * * * \\
(4.32)\end{array}$ & $\begin{array}{l}0.0092^{* * * *} \\
(4.28)\end{array}$ \\
\hline $\log ($ Capital $) \cdot$ HighIncome & $\begin{array}{l}0.69 \text { *** } \\
(35.58)\end{array}$ & $\begin{array}{l}0.65^{* * * *} \\
(25.08)\end{array}$ \\
\hline $\log ($ Capital $) \cdot$ LowIncome & $\begin{array}{l}0.69 * * * \\
(35.58)\end{array}$ & $\begin{array}{l}0.65^{* * * *} \\
(25.08)\end{array}$ \\
\hline $\log ($ Labor $) \cdot$ HighIncome & $\begin{array}{l}0.57^{* * * *} \\
(33.80)\end{array}$ & $\begin{array}{l}0.59^{* * * *} \\
(41.30)\end{array}$ \\
\hline $\log ($ Labor $) \cdot$ LowIncome & $\begin{array}{l}0.21 * * * \\
(5.89)\end{array}$ & $\begin{array}{l}0.34^{* * * *} \\
(8.37)\end{array}$ \\
\hline Selection $\cdot$ CommonLaw & $\begin{array}{l}0.026^{* * * *} \\
(3.43)\end{array}$ & $\begin{array}{l}0.027^{* * *} \\
(3.54)\end{array}$ \\
\hline Selection $\cdot$ ContinentalLaw & $\begin{array}{l}-0.022^{* * * *} \\
(-3.51)\end{array}$ & $\begin{array}{l}-0.0091 * \\
(-1.71)\end{array}$ \\
\hline Selection $\cdot$ Socialist & $\begin{array}{l}-0.070^{* * * *} \\
(-3.91)\end{array}$ & $\begin{array}{l}-0.099 * * * \\
(-6.45)\end{array}$ \\
\hline Accession $\cdot$ CommonLaw & $\begin{array}{l}0.0042 \\
(1.53)\end{array}$ & $\begin{array}{l}0.0041 \\
(1.49)\end{array}$ \\
\hline Accession $\cdot$ ContinentalLaw & $\begin{array}{l}0.0041^{*} \\
(1.83)\end{array}$ & $\begin{array}{l}0.0064^{* * *} \\
(2.67)\end{array}$ \\
\hline Accession $\cdot$ Socialist & $\begin{array}{l}0.0040 \\
(0.50)\end{array}$ & $\begin{array}{l}-0.011^{*} \\
(-1.65)\end{array}$ \\
\hline Import/GDP & & $\begin{array}{l}-0.0031^{* * *} \\
(-8.45)\end{array}$ \\
\hline Export/GDP & & $\begin{array}{l}0.0055^{* * * *} \\
(13.13)\end{array}$ \\
\hline FDI/GDP & & $\begin{array}{l}-0.00041 \\
(-0.60)\end{array}$ \\
\hline Intercept & $\begin{array}{l}-28.96^{* * *} \\
(-21.96)\end{array}$ & $\begin{array}{l}-8.93^{* * *} \\
(-6.15)\end{array}$ \\
\hline$R^{2}$ & 0.862 & 0.872 \\
\hline No. of observations & 3,377 & 2,304 \\
\hline
\end{tabular}

Notes: See table 4.9.

***Significant at the 1 percent level.

*Significant at the 10 percent level. 
Table 4.24

Production Function Regressions with Legal Origin Dummies Using Predicted GATT/WTO Membership to Control for Selection Endogeneity

\begin{tabular}{|c|c|c|}
\hline & \multicolumn{2}{|c|}{ Dependent Variable } \\
\hline & $\log (\mathrm{GDP})$ & $\log (\mathrm{GDP})$ \\
\hline Year $\cdot$ CommonLaw & $\begin{array}{l}0.026^{* * *} \\
(16.75)\end{array}$ & $\begin{array}{l}0.019^{* * * *} \\
(9.31)\end{array}$ \\
\hline Year $\cdot$ ContinentalLaw & $\begin{array}{l}0.022^{* * *} \\
(19.64)\end{array}$ & $\begin{array}{l}0.0039^{* * *} \\
(3.15)\end{array}$ \\
\hline Year $\cdot$ Socialist & $\begin{array}{l}0.0078 * * * \\
(3.75)\end{array}$ & $\begin{array}{l}0.0054^{* *} \\
(2.54)\end{array}$ \\
\hline $\log ($ Capital $) \cdot$ HighIncome & $\begin{array}{l}0.71^{* * *} \\
(36.36)\end{array}$ & $\begin{array}{c}0.65^{* * * *} \\
(25.37)\end{array}$ \\
\hline $\log ($ Capital $) \cdot$ LowIncome & $\begin{array}{l}0.58^{* * * *} \\
(34.79)\end{array}$ & $\begin{array}{l}0.60 * * * \\
(41.76)\end{array}$ \\
\hline $\log ($ Labor $) \cdot$ HighIncome & $\begin{array}{l}0.074 * * \\
(1.97)\end{array}$ & $\begin{array}{l}0.33^{* * *} \\
(6.22)\end{array}$ \\
\hline $\log ($ Labor $) \cdot$ LowIncome & $\begin{array}{l}0.18^{* * * *} \\
(4.86)\end{array}$ & $\begin{array}{l}0.35^{* * * *} \\
(8.76)\end{array}$ \\
\hline Selection $\cdot$ CommonLaw & $\begin{array}{l}-0.0087^{* * * *} \\
(-5.62)\end{array}$ & $\begin{array}{l}-0.011^{* * *} \\
(-5.57)\end{array}$ \\
\hline Selection $\cdot$ ContinentalLaw & $\begin{array}{l}-0.0050 * * * \\
(-5.16)\end{array}$ & $\begin{array}{l}0.00074 \\
(0.80)\end{array}$ \\
\hline Selection $\cdot$ Socialist & $\begin{array}{l}-0.042^{* * *} \\
(-3.34)\end{array}$ & $\begin{array}{l}-0.0032^{* * *} \\
(-0.32)\end{array}$ \\
\hline Accession $\cdot$ CommonLaw & $\begin{array}{l}0.0095^{* * *} \\
(3.72)\end{array}$ & $\begin{array}{l}0.0068^{* * *} \\
(2.65)\end{array}$ \\
\hline Accession $\cdot$ ContinentalLaw & $\begin{array}{l}0.0020 \\
(0.97)\end{array}$ & $\begin{array}{l}0.0049 * * \\
(2.19)\end{array}$ \\
\hline Accession $\cdot$ Socialist & $\begin{array}{l}-0.0029 \\
(-0.38)\end{array}$ & $\begin{array}{l}-0.014^{*} \\
(-1.93)\end{array}$ \\
\hline Import/GDP & & $\begin{array}{l}-0.0033^{\text {*** }} \\
(-8.98)\end{array}$ \\
\hline Export/GDP & & $\begin{array}{l}0.0055^{* * *} \\
(13.08)\end{array}$ \\
\hline FDI/GDP & & $\begin{array}{l}-0.00017 \\
(-0.25)\end{array}$ \\
\hline Intercept & $\begin{array}{l}-36.85^{* * *} \\
(-21.86)\end{array}$ & $\begin{array}{l}-13.64 * * * \\
(-7.05)\end{array}$ \\
\hline$R^{2}$ & 0.863 & 0.870 \\
\hline No. of observations & 3,377 & 2,304 \\
\hline
\end{tabular}

Notes: See table 4.10.

*** Significant at the 1 percent level.

**Significant at the 5 percent level.

*Significant at the 10 percent level. 
them became members of GATT/WTO during the sample period. We study the changes in GDP growth, capital stock, import, export, FDI, and TFP of the accession economies around the year of joining GATT/WTO, using the rest of economies as references. We allow the possibility that different types of economies responded differently around the event. The classifications of the type of the economies are by per capita income and by initial economic institutions.

The findings indicate that the economy group with per capita income higher than US $\$ 3,000$ (in 1987) benefited much more than the lowerincome group. Countries of common-law origin benefited much more than those of continental-law origin. The former socialist economies had little gain associated with the accession. These findings cast serious doubt on the commonly received belief that backwardness in economic development is an advantage of economic growth. Instead, the findings provide evidence that having proper initial economic institutions is important for economic development via globalization for a developing economy.

\section{References}

Brecher, Richard, and Carlos Diaz-Alejandro. 1977. Tariffs, foreign capital, and immiserizing growth. Journal of International Economics 7 (2): 317-22.

Fernandez de Cordoba, Gonzalo, and Timothy J. Kehoe. 2000. Capital flows and real exchange rate fluctuations following Spain's entry into the European community. Journal of International Economics 51 (1): 49-78.

Gerschenkron, Alexander. 1962. Economic backwardness in historic perspective. Cambridge, Mass.: Harvard University Press.

Harrison, Ann. 1996. Openness and growth: A time-series, cross-country analysis for developing countries. Journal of Development Economics 48:419-47.

Heckman, James, and V. Joseph Hotz. 1989. Choosing among alternative nonexperimental methods for estimating the impact of social programs: The case of manpower training. Journal of the American Statistical Association 84:862-80.

Kenny, Charles, and David Williams. 2001. What do we know about economic growth? Or, why don't we know very much? World Development 29 (1): 1-22.

La Porta, Rafael, Florencio Lopez-de-Silanes, Andrei Shleifer, and Robert Vishny. 1999. The quality of government. Journal of Law and Economics and Organization 154 (1): 222-79.

MacKinlay, Graig. 1997. Event studies in economics and finance. Journal of Economic Literature 35 (1): 13-39.

Milthorp, Peter. 1997. Integration of former Soviet Union economies in transition into the World Trade Organization. Economics of Transition 5 (1): 215-23.

Mutti, Jack, Rachelle Sampson, and Bernard Yeung. 2000. The effects of the Uruguay Round: Empirical evidence from US industry. Contemporary Economic Policy 18 (1): 59-86.

Nelson, Richard R., and Bhaven N. Sampat. 2001. Making sense of institutions as a factor shaping economic performance. Journal of Economic Behavior \& Organization 44 (1): 31-54. 
Rodriguez, Francisco, and Dani Rodrik. 2000. Trade policy and economic growth: A skeptic's guide to the cross-national evidence. Harvard University, Kennedy School of Government. Working Paper.

Rodrik, Dani. 1997. Has globalization gone too far? Washington, D.C.: Institute for International Economics, March. Mimeograph.

Rose, Andrew K. 2002. Do we really know that WTO increases trade? NBER Working Paper no. 9273. Cambridge, Mass.: National Bureau of Economic Research.

Stiglitz, Joseph E. 2002. Globalization and its discontents. New York: W. W. Norton.

\section{Comment Simon Johnson}

The authors have selected an excellent topic. Does joining the WTO help or hurt economic growth? There are some interesting rival hypotheses. For example, perhaps foreign direct investment will decline after a country joins the WTO, as firms no longer have an incentive to engage in "tariff wall jumping." More generally, there may be two forms of WTO accession: those that genuinely promote more trade and growth, and those that primarily benefit a controlling elite by facilitating greater expropriation of one form or another. It is also theoretically possible that WTO accession might lead to more or less political instability.

This paper offers an appealing event-study-type methodology to study accession. Looking at a window of $(-5,+10)$ and using annual data and country fixed effects for all countries that joined GATT/WTO since 1960 is surely a sensible way to proceed. It is also attractive to start with simple measures and then add more complex indicators of performance. Dividing countries into low, middle, and high income is reasonable, although it does prompt the reader to wonder about deeper underlying causes of per capita income levels (e.g., is this the result of institutions or geographical conditions or something else that might cause an important omitted variable problem?) Examining the effect of initial institutions is also an important step.

The authors' findings are thought-provoking, and they have done us a great service by pulling together an invaluable data set (table 4.1 will be widely cited). I'm sure they (and others) will subject their results to a great deal more in the form of robustness checks, particularly looking at the effects of institutions. Examining five-year average values or decade averages (before and after) would be appealing. We also need more detail on when exactly negotiations began, in order to think about alternative "win-

Simon Johnson is the Ronald A. Kurtz Associate Professor at the Sloan School of Management, Massachusetts Institute of Technology, and a faculty research fellow of the National Bureau of Economic Research. 
dows." Given the work by Dani Rodrik and Bill Easterly on the slowdown of growth in developing countries, we particularly need to see various alternative controls for time effects (Rodrik 1999; Easterly 2001).

Looking forward to the research that will build on this paper, researchers must get to grips with the mechanism through which WTO accession brings economic benefits. Reducing tariffs and nontariff barriers may have direct positive effects. It could also be the case that accession is a form of commitment by local elites not to engage in some forms of expropriation. This appears to be an important role of European Union (EU) accession in Eastern Europe-political elites in Hungary and Poland, for example, are much more constrained than their counterparts in Belarus and Ukraine, because breaking with the EU accession process would have large political and economic costs. But how general is this effect?

Future research could use the method of Rajan and Zingales (1998), or perhaps the recent alternative proposal of Fisman and Love (2002), to look more at which sectors grow faster and slower with WTO accession. To what extent do the sectoral effects vary with income level or institutions? Is there any indication that the rich and powerful within countries gain disproportionately?

The main worry with this kind of study is of course identification. Perhaps it is the case that countries join the WTO when they were going to grow anyway. The authors again take an important step in their analysis of selection, but in the next round of research, we should look for situations in which the trade regime is in some sense exogenous - that is, the effect of joining the WTO is well identified. Alternatively, we need an instrumental variable that both is correlated with trade liberalization and can be excluded from the main regression. Studies of trade and financial liberalization currently lack such instruments.

The emerging conventional wisdom on liberalizations seems to be some form of the new "Columbia School" view. There are differences in the views of Bhagwati, Sachs, Stiglitz, and Rodrik (formerly at Columbia) on this issue, but all warn strongly against financial liberalization, particularly as it may lead to vulnerability to panics and speculative attacks (Bhagwati 1998; Radelet and Sachs 1998; Sachs and Warner 1997; Stiglitz 2002; Rodrik 1997). At the same time, at least three of these four remain broadly sympathetic to trade liberalization. The next generation of research will hopefully test these ideas directly and with properly identified regressions.

Some of the historical evidence should make us cautious about expecting all trade liberalizations to have positive effects. The rapid growth of external trade in Europe after 1500 was associated with very different economic and political changes in different places. In Northwest Europe the growth of trade led to broad-based economic progress, contributing to the conditions that made the Industrial Revolution possible. In Spain and Por- 
tugal, the growth of trade strengthened absolutist monarchs as they captured important new cash revenues. And in Eastern Europe the evidence suggests that growing trade may have contributed to the so-called "second serfdom." Who wins and who loses from the growth of trade may depend a great deal on the precise nature of initial institutions and the distribution of power within society.

\section{References}

Bhagwati, Jagdish N. 1998. The capital myth. Foreign Affairs 77 (3): 7-12.

Easterly, William. 2001. The lost decades: The developing countries' stagnation in spite of policy reform. Journal of Economic Growth 9:135-57.

Fisman, Raymond, and Inessa Love. 2002. Patterns of industrial development revisited: The role of finance. Columbia University and The World Bank. Unpublished manuscript.

Radelet, Steven, and Jeffrey D. Sachs. 1998. The East Asian financial crisis: Diagnosis, remedies, prospects. Brookings Papers on Economic Activity, Issue no. 1: $1-90$.

Rajan, Raghuram, and Luigi Zingales. 1998. Financial dependence and growth. American Economic Review 88:559-86.

Rodrik, Dani. 1997. Has globalization gone too far? Washington, D.C.: Institute for International Economics, March.

1999. Where did all the growth go? External Shocks, Social Conflict, and Growth Collapses. Journal of Economic Growth 4 (4): 385-412.

Sachs, Jeffrey D., and Andrew Warner. 1997. Fundamental sources of long-run growth. American Economic Review 87 (2): 184-88.

Stiglitz, Joseph E. 2002. Globalization and its discontents. New York: W. W. Norton.

\section{Comment Epictetus E. Patalinghug}

\section{Introduction}

The study by $\mathrm{Li}$ and $\mathrm{Wu}$ attempts to assess the impact of the GATT/ WTO accession on the domestic economy. It adopts the event-study method to assess the impact of the WTO on the domestic economy. The authors used this method in two ways: (1) to assess the impact of the accession on each of the economic variables (e.g., GDP, capital formation, import, export, and FDI), and (2) to assess the impact of the accession on the economywide productivity. The following discussion provides comments on the link between the WTO accession and market access. It likewise dis-

Epictetus E. Patalinghug is professor of economics and management in the College of Business Administration, University of the Philippines. 
cusses the logic of the regression results vis-à-vis the assumed hypothesis. And it concludes with suggestions on improving the style of the paper.

\section{WTO Accession and Market Access}

The objective of assessing the impact of the GATT/WTO accession on the domestic economy is a desirable one. However, the assumption that accession is identical with market access, as well as with the reduction in tariff and nontariff barriers, is not. The hypothesis of the study that GATT/ WTO accession usually means better market access for foreign investors and therefore stimulates the inflow of FDI is most probably inappropriate. In reality, WTO accession in many countries may not be identical with market access or tariff reduction several years after accession. Several countries negotiate the magnitude, extent, and timing of their market access or tariff-reduction commitments before accession. Consider the case of two WTO member countries: the Philippines and Thailand. The Philippines was accepted into GATT in 1979 and Thailand in 1982. But until very recently trade in motor vehicles, cement, sugar, and rice (among other commodities) between the two countries is still hampered by relatively high tariff rates.

Special and differential treatment (SND) for developing countries is acknowledged as an integral part of WTO negotiations and WTO rules. The Agreement on Agriculture provided SND to developing countries in the form of (1) lesser reduction commitments on market access, export subsidies, and domestic support; (2) longer time frames for implementation of commitments; (3) greater market access in developed countries; and (4) exemption from reduction commitments (e.g., investment subsidies, agricultural input subsidies, subsidies to reduce marketing cost of agricultural products, etc.). This aspect of WTO negotiation implies that accession is not identical with market access.

In some instances, trade patterns are not very sensitive to changes in tariff rates. The volume of intra-Association of Southeast Asian Nations (ASEAN) trade has not increased beyond the 17-23 percent range after the gradual implementation of the ASEAN Free Trade Area (AFTA) tariff rates. Singapore accounts for most of the intra-ASEAN trade (Austria and Avila 2001; Teh 1993). On the contrary, the volume of trade between individual ASEAN countries and the United States or Japan (e.g., SingaporeUnited States trade or Thailand-Japan trade) is much larger than any bilateral intra-ASEAN trade. This pattern continues even if WTO tariff rates are relatively higher than AFTA tariff rates.

\section{Regression Results}

The regression results on the impact of the accessions on the growth rate of GDP indicate that high-income economies experienced a positive impact of about a 1.5 percent to 1.6 percent increase in the GDP growth rate 
per year for ten years after accession, while no significant increase was observed for low-income economies after accession. Similarly, high-income countries experienced significant increases in growth of capital, growth of import, growth of export, growth of FDI, and growth of total factor productivity as compared to low-income countries. Based on these findings, the authors conclude that the advantage of backwardness as hypothesized by Gerschenkron does not apply in this case; rather, they assert that what is more important are the initial economic institutions before joining GATT/WTO. The authors' empirical findings are consistent with the growing perception of less-developed country (LDC) members of WTO that the 1995 WTO agreements were disadvantageous to them. These findings provide support to LDCs' attempt to eliminate or prohibit in the WTO Agreement on Agriculture the practice of twenty-five developed countries of continuing to provide export subsidies. This is the biggest contributor to unfair trade in agriculture.

One conclusion from the authors' findings is that trade liberalization due to WTO accession has a varying impact on each country (low-income country vs. high-income country, or common-law country vs. socialist country). Some studies suggested that trade-GDP ratios fall as per capita income rises, while other studies showed that export-promoting economies exhibited a rise in trade-GDP ratios as per capita incomes grew rapidly. Among the GATT/WTO member countries, export-promoting countries may emerge as more successful compared to import-substituting countries (Bhagwati 1988). Although WTO accession can be interpreted as accelerating the momentum for a freer world trading system, this study's findings support the view that trade-GDP ratio increases as per capita income rises. But its most revealing finding is that WTO accession is not an opportunity to level the playing field. On the contrary, it favors high-income economies that are initially endowed with good economic institutions.

\section{Selection Endogeneity}

In addressing the issue of selection endogeneity, the authors employed two measures of the selection variable: one using the Heckman-Hotz method, and the other using the estimated qualification date that is predicted by fitting a probit regression method. In analyzing its findings, the authors conveniently cite the estimates from either measure, whichever is significant or sensible. Since the impact of the economic variables on accession does not change significantly by using either of the two alternative approaches to control for the selection effect, the paper would be reduced to a manageable length if it simply presented the regression estimates using the Heckman-Hotz method. In its present form, more than 50 percent of the paper consists of tables from alternative regression runs, whose inclusion in the paper has marginal contribution in the analysis of its findings. 


\section{Conclusion}

Nevertheless, this paper is a pioneering effort at assessing the impact of GATT/WTO accession across countries.

\section{References}

Austria, Myrna, and John Lawrence Avila. 2001. Looking beyond AFTA: Prospects and challenges for inter-regional trade. Philippine Journal of Development 28 (2): 143-66.

Bhagwati, Jagdish. 1988. Export-promoting trade strategy: Issues and evidence. World Bank Research Observer 3 (1): 27-57.

Teh, Robert. 1993. Implementing the CEPT mechanism and Philippine trade and resource flows. In The ASEAN free trade area, ed. Mario Lamberte, 21-38. Manila: Philippine Economic Society. 